\title{
RESEARCH
}

Open Access

\section{Differential effects of chronic immunosuppression on behavioral, epigenetic, and Alzheimer's disease- associated markers in 3xTg-AD mice}

Minesh Kapadia', M. Firoz Mian², Donglai Ma ${ }^{3}$, Craig P. Hutton ${ }^{4}$, Amber Azam $^{5}$, Klotilda Narkaj ${ }^{5}$, Chuanhai Cao $^{6}$, Breanna Brown ${ }^{6}$, Bernadeta Michalski ${ }^{1}$, David Morgan ${ }^{7}$, Paul Forsythe ${ }^{2}$, Iva B. Zovkic ${ }^{5}$, Margaret Fahnestock ${ }^{1}$ and Boris Sakic ${ }^{1 *}$ (D)

\begin{abstract}
Background: Circulating autoantibodies and sex-dependent discrepancy in prevalence are unexplained phenomena of Alzheimer's disease (AD). Using the 3xTg-AD mouse model, we reported that adult males show early manifestations of systemic autoimmunity, increased emotional reactivity, enhanced expression of the histone variant macroH2A1 in the cerebral cortex, and loss of plaque/tangle pathology. Conversely, adult females display less severe autoimmunity and retain their AD-like phenotype. This study examines the link between immunity and other traits of the current 3xTg-AD model.

Methods: Young 3xTg-AD and wild-type mice drank a sucrose-laced $0.4 \mathrm{mg} / \mathrm{ml}$ solution of the immunosuppressant cyclophosphamide on weekends for 5 months. After behavioral phenotyping at 2 and 6 months of age, we assessed organ mass, serologic markers of autoimmunity, molecular markers of early AD pathology, and expression of genes associated with neurodegeneration.

Results: Chronic immunosuppression prevented hematocrit drop and reduced soluble A $\beta$ in 3xTg-AD males while normalizing the expression of histone variant macroH2A1 in 3xTg-AD females. This treatment also reduced hepatosplenomegaly, lowered autoantibody levels, and increased the effector $T$ cell population while decreasing the proportion of regulatory $T$ cells in both sexes. Exposure to cyclophosphamide, however, neither prevented reduced brain mass and BDNF expression nor normalized increased tau and anxiety-related behaviors.
\end{abstract}

Conclusion: The results suggest that systemic autoimmunity increases soluble A $\beta$ production and affects transcriptional regulation of macroH2A1 in a sex-related manner. Despite the complexity of multisystem interactions, 3xTg-AD mice can be a useful in vivo model for exploring the regulatory role of autoimmunity in the etiology of AD-like neurodegenerative disorders.

Keywords: Alzheimer's disease, 3xTg-AD mice, Autoimmunity, Cyclophosphamide, T lymphocytes, Autoantibodies, Amyloid-beta, Tau, BDNF, Histone variants, Sex

\footnotetext{
* Correspondence: sakic@mcmaster.ca

'Department of Psychiatry and Behavioral Neurosciences, McMaster

University, 1280 Main St. West, Hamilton, ON L8S 4K1, Canada

Full list of author information is available at the end of the article
}

\section{$\triangle B M C$}

(c) The Author(s). 2021 Open Access This article is licensed under a Creative Commons Attribution 4.0 International License, which permits use, sharing, adaptation, distribution and reproduction in any medium or format, as long as you give appropriate credit to the original author(s) and the source, provide a link to the Creative Commons licence, and indicate if changes were made. The images or other third party material in this article are included in the article's Creative Commons licence, unless indicated otherwise in a credit line to the material. If material is not included in the article's Creative Commons licence and your intended use is not permitted by statutory regulation or exceeds the permitted use, you will need to obtain permission directly from the copyright holder. To view a copy of this licence, visit http://creativecommons.org/licenses/by/4.0/ The Creative Commons Public Domain Dedication waiver (http://creativecommons.org/publicdomain/zero/1.0/) applies to the data made available in this article, unless otherwise stated in a credit line to the data. 


\section{Introduction}

Alzheimer's disease (AD) is a neurodegenerative disorder that disproportionately affects women, both in prevalence and severity [5, 36, 65]. Although the causes for this discrepancy remain poorly understood, factors beyond longevity have been implicated [2, 24]. Recent genomic $[44,47,64]$ and clinical studies $[8,62,77,104,111]$ point to the involvement of the immune system in the etiology of AD. However, the possibility that sex-specific differences in immunity [61] underlie increased disease prevalence in females has not been explored. One limiting factor is the dearth of appropriate animal models in which the causal relationships between the immune system, sex, and AD-like neuropathology can be studied in a controlled and systematic manner.

The triple transgenic (3xTg-AD) mouse model is a widely used tool for studying $\mathrm{AD}$ pathogenesis [12] because it develops age-related cognitive impairments and soluble intraneuronal amyloid-beta $(\mathrm{A} \beta)$ oligomers by 6 months of age and neuritic plaques and neurofibrillary tangles in the cortex and hippocampus after 12 months of age $[13,82,83]$. The $3 x$ Tg-AD mouse model has been instrumental in documenting how $A \beta$ contributes to tauopathy $[84,119]$, how soluble $A \beta$ and tau contribute to early stages of the disease [43, 93], and how inflammation potentiates neuropathology [54, 60, 114]. More recently, we observed that in 3xTg-AD mice, behavioral deficits similar to mild cognitive impairment appear as a prodrome to subsequent decline in spatial learning/ memory task performance [50, 69]. Namely, between 2 and 6 months of age, these mice display pronounced anxiety-related behaviors (e.g., "acrophobia" in the stepdown test and elevated plus maze, altered exploration of the open field, and enhanced thigmotaxis in a swimming pool), changes in olfactory sensitivity, and impairments in cognitive flexibility when tested in reversal trials of the Morris water maze [50, 69]. Coinciding with these behavioral changes is the spontaneous development of a progressive systemic autoimmune response, as evidenced by splenomegaly, hepatomegaly, elevated serum levels of anti-nuclear/anti-dsDNA antibodies, low hematocrit, and increased number of double-negative $\mathrm{T}$ splenocytes [69]. Importantly, this immune activation in 3xTg-AD males manifests as early as 1.5 month of age, well before the earliest documented signs of neuropathology [69], and persists even at older ages [29]. When compared to wild-type males, AD males also show increased expression of macroH2A1 (mH2A1) [56], which is a variant of the canonical histone $\mathrm{H} 2 \mathrm{~A}$, important in neuroplasticity and often upregulated during neurodegenerative processes [31, 49]. Paradoxically, the brains of 1-year-old males no longer show plaque and tangle deposits. This loss of AD-like pathology in some male cohorts was confirmed independently by the donating investigator in 2014 (https://www.jax.org/strain/004807).

In comparison to 3xTg-AD males, 1-year-old 3xTg$\mathrm{AD}$ females still show $\mathrm{A} \beta$ plaque deposition in the cortex and hyperphosphorylated tau tangles in the hippocampus [10], in parallel with development of milder autoimmune manifestations [56]. This sex-dependent shift in phenotypic traits is not isolated to a single colony, as several independent groups have documented sex differences in behavior $[14,15,19,26,40,90,91,96$, 109, 112, 117], AD-like neuropathology [21, 46, 88, 90, 91], response to environmental enrichment or exercise $[3,38,42,116]$, life span $[40,92]$, and immunity [40, 42]. Importantly, many of these sex-specific differences are apparent within the first 6 months of life $[19,21,26,38$, 42, 56, 90, 91, 96, 109]. Jointly, these findings suggest that adult male 3xTg-AD mice develop a stronger autoimmune response than females that alters their behavioral profile early in the course of the disease and is associated with a delay in AD-like pathology in comparison to female littermates. However, no study to date has systematically examined the cause-effect relationship between spontaneous peripheral immune activation, early behavioral dysfunction, and prodromal markers of $\mathrm{AD}$ like pathology in both male and female 3xTg-AD mice. To test the nature of sex-related systemic autoimmunity in the context of the altered 3xTg-AD phenotype, the current study compares molecular, cellular, and functional consequences of prolonged immunosuppressive treatment in adult male and female 3xTg-AD and wildtype mice.

The alkylating agent cyclophosphamide (CY) is effective in arresting systemic autoimmunity via its metabolite phosphoramide mustard, which is formed in cells with low levels of aldehyde dehydrogenase and leads to apoptosis by forming DNA crosslinks. Given that chronic exposure to CY prevents neurodegeneration and normalizes behavior in autoimmune mice [58, 101-103], an identical, well-established protocol that does not involve injection-induced stress was chosen as a treatment modality in the current study. To provide consistency and comparability across studies, previously used behavioral, cellular, and molecular variables $[56,69]$ were analyzed.

\section{Materials and methods \\ Animals}

Colonies of homozygous 3xTg-AD mice containing $P S 1_{\mathrm{M} 146 \mathrm{~V}}, A P P_{\text {swe }}$, and $\operatorname{tau}_{\mathrm{P} 301 \mathrm{~L}}$ mutations and wild-type (WT), non-transgenic controls of the same mixed B6129SF2 background were established from breeders purchased from the Jackson Laboratories (Bar Harbor, ME, USA). In order to age-match the animals, in-house litters born on the same date ( \pm 3 days) were selected for 
the current study and tested in parallel. Due to inherent differences in the size of litters among 3xTg-AD breeders versus WT breeders, the final number of animals included was 69 3xTg-AD mice and 75 WT mice. Pups were weaned at 21 days of age and housed in same-sex, age-matched groups of 3 to 5 littermates under the following laboratory conditions: $22^{\circ} \mathrm{C}, 60 \%$ humidity, ad lib access to low-fat rodent chow and water in $150 \mathrm{ml}$ leak-proof bottles, and on a reverse 12-h light/ dark cycle. They were tail-tattooed with AIMS ${ }^{\text {mi }}$ ATS-3 System at the beginning of the study and weighed every 2 weeks. All experimental protocols were performed with the approval of the local Animal Care Committee and the Canadian Council on Animal Care.

\section{Immunosuppressive treatment}

Four-week-old mice were assigned to one of 8 groups ( $n=13-21 \mathrm{mice} /$ group) according to substrain (3xTg$\mathrm{AD}$ vs. WT), sex (male vs. female), and treatment (CY vs. vehicle, Veh). They were given to drink an aqueous solution of CY (diluted to $0.4 \mathrm{mg} / \mathrm{ml}$, "Procytox," Baxter, Mississauga, $\mathrm{ON}$ ), an immunosuppressive drug, laced with $16 \%$ sucrose, or sucrose-only solutions (vehicle) in place of water bottles, available ad libitum over the weekends for 5 months. Such a non-invasive administration route was chosen to avoid confounding effects of repeated pain- and restraint-induced stress on behavioral performance [7, 74, 98]. Moreover, due to its metallic taste, $\mathrm{CY}$ was laced with sucrose to increase palatability and thus achieve the therapeutic dose range previously shown to attenuate systemic autoimmunity and normalize functional deficits in lupus-prone mice [57]. In order to assess general CY toxicity, we similarly treated WT mice to control for multisystem effects of $\mathrm{CY}$ and its metabolites that are not related to the immune system. Mice were individually housed, and either $\mathrm{CY}$ or Veh solutions were administered throughout the duration of the study until sacrifice at $\sim 6.5$ months of age. Total volume consumed per weekend was monitored, and the amount of $\mathrm{CY}$ consumed by each mouse was recorded at the beginning of the study (1-2 months of age) and at the end of the study (5-6 months of age). The final number of animals in each group was as follows: WT Veh males $(n=16)$, WT CY males $(n=20)$, 3xTg-AD Veh males $(n=13)$, 3xTg-AD CY males $(n=$ $17)$, WT Veh females $(n=18)$, WT CY females $(n=21)$, $3 x T g-A D$ Veh females $(n=14)$, and 3xTg-AD CY females $(n=15)$.

\section{Behavioral battery}

Following an initial 5-day habituation period, all mice underwent behavioral phenotyping from 1.5 to 2.5 months and again from 5.5 to 6.5 months of age (Fig. 1a). These periods correspond to timepoints at which $3 \times \mathrm{Tg}$ -
AD mice are documented to exhibit anxiety-like behaviors, altered olfactory sensitivity [50, 69], and learning/ memory impairment, accompanied by accumulation of intraneuronal $A \beta$ in the hippocampus and amygdala [13, 82]. In each block, mice were exposed to tests reflective of neurological/sensorimotor function, spontaneous locomotor activity, and emotional reactivity. These tests were performed during the dark phase in the following order: basic reflexes, beam-walking, Rotarod, olfactory sensitivity, T-maze alternation, novel object, open field, step-down, Morris water maze, and spontaneous activity, as described earlier in detail $[55,69,100]$.

\section{Tissue collection}

Approximately 7-month-old mice were anesthetized with a ketamine/xylazine cocktail, and retro-orbital blood samples were collected. Whole blood was collected after severing the inferior vena cava and centrifuged for $5 \mathrm{~min}(10,000 \times g$, Eppendorf MiniSpin Plus; Fisher Scientific Canada, Ottawa, ON, Canada). Serum was separated from the clot and stored at $-20^{\circ} \mathrm{C}$ for quantification of autoantibodies. Mice were intracardially perfused with $\sim 120 \mathrm{ml}$ of phosphate-buffered saline (PBS) over $5 \mathrm{~min}$, and tissues were harvested and wet weighed as previously described [69]. Spleens were wet weighed, collected in cold PBS, kept on ice, and then processed for flow cytometry analysis of $\mathrm{T}$ splenocyte distribution. Brains were wet weighed before separating cortical hemispheres, which were flash frozen in liquid nitrogen and stored at $-80^{\circ} \mathrm{C}$ for molecular assays.

\section{Assessment of autoimmunity markers}

Hematocrit was measured to assess the volume percentage of red blood cells in blood, as low hematocrit can be a sign of autoimmune hemolytic anemia. Retro-orbital blood samples from anesthetized animals were collected in heparinized Fisher microhematocrit capillary tubes just prior to sacrifice. Sealed tubes were centrifuged for $10 \mathrm{~min}$ in a standard microhematocrit centrifuge (ClayAdams, Parsippany, NJ, USA) and read in a Critocaps reader.

Anti-nuclear antibody (ANA) positivity in sera, a hallmark of systemic autoimmunity, was assessed using an immunofluorescence assay (HEp2010 cells, EUROIMMUN Canada, Mississauga, ON, Canada) according to the manufacturer's instructions [56]. Semi-quantitative assessment of nuclear staining patterns was performed by an unbiased assessor according to a 1-4 scale using LED-fluorescence microscopy (EUROStar III, EUROIMMUN). Staining patterns were classified based on standardized nomenclature of ANA-HEp-2 cell patterns established by the International Consensus on Antinuclear Antibody (ANA) Patterns, ICAP [22]. In addition to semi-quantitative scoring of ANA positivity, 


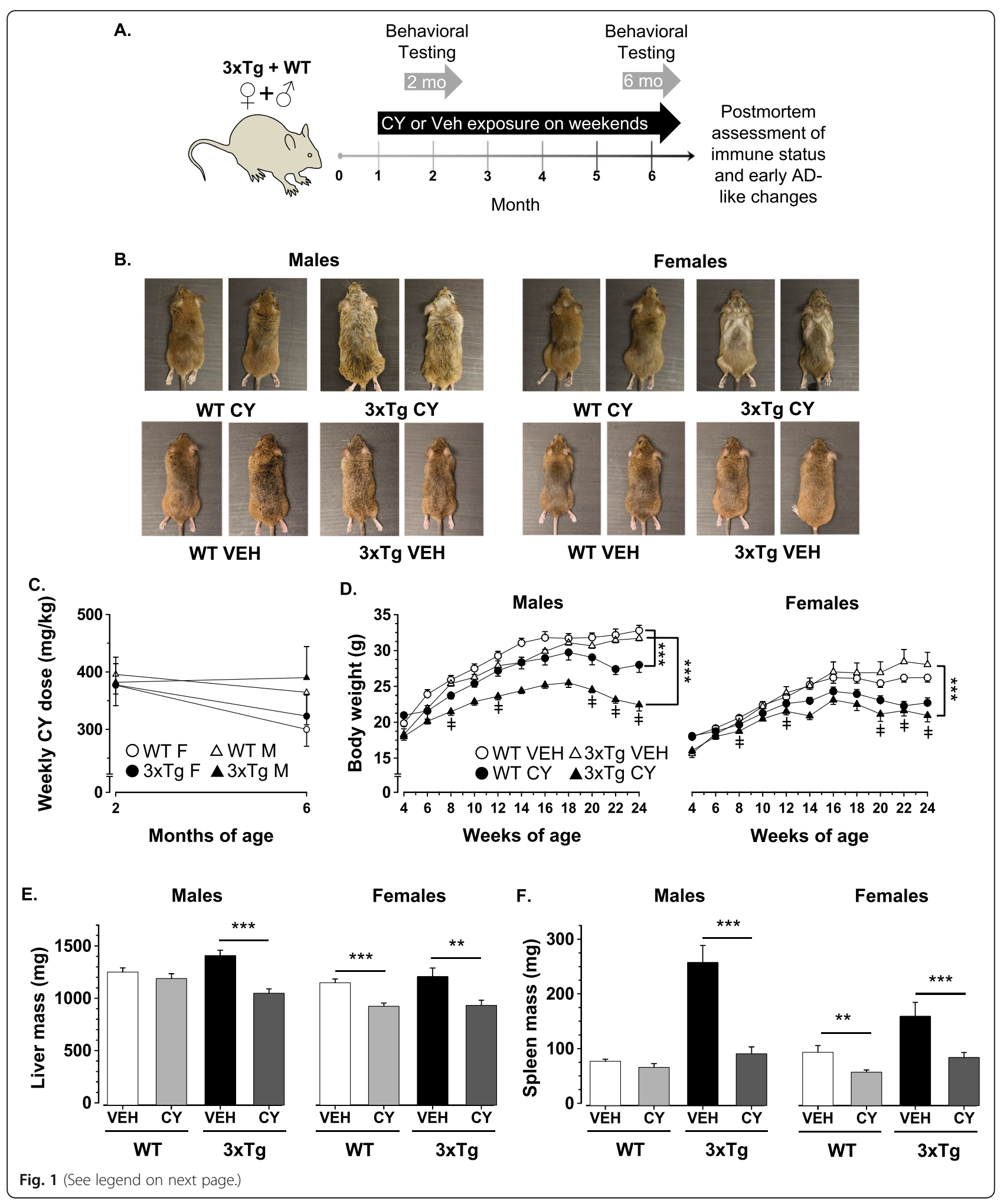


(See figure on previous page.)

Fig. 1 Cyclophosphamide (CY)-induced alterations in peripheral indicators. a Study design and experimental timeline diagram depicting the age and testing timepoints for data collected. In brief, 1-month-old 3xTg-AD and WT mice of both sexes were randomly assigned to receive treatment with CY or vehicle solution on weekends until 6.5 months of age ( $n=13-21$ mice/group). All mice were tested in a behavioral battery between 1.5 and 2.5 months of age (2-month timepoint) and re-evaluated between 5.5 and 6.5 months of age (6-month timepoint) to determine the short- and long-term effects of CY treatment. After the behavioral testing was completed, at 6.5 months of age, mice were euthanized and tissues were collected for biomarker assays (see text). b Representative photos showing ruffled and depigmented fur in cyclophosphamide (CY)-treated 3xTg-AD males and a distinct, V-pattern of graying commonly seen in 3xTg-AD females. Alterations in fur quality or condition were not noticeable in CY-exposed WT controls or in vehicle-treated (Veh) groups. c Mice with access to CY on weekends voluntarily ingested similar doses (mg/kg/weekend) of the immunosuppressant at $\sim 2$ (WT males, $377 \pm 37$; 3xTg-AD males, $382 \pm 20$; WT females, 377 \pm 36 ; 3xTg-AD females, $396 \pm 30$ ) and $\sim 6$ months of age (WT males, $323 \pm 37$; 3xTg-AD males, $390 \pm 54$; WT females, $300 \pm 30 ; 3 x T g-A D$ females, $364 \pm 56$ ). $\mathbf{d}$ Sustained exposure to CY (closed symbols), but not vehicle solution (open symbols), induced loss of body mass that was more severe in the 3xTg-AD substrain (triangle) than in WT controls (circles) and became more apparent at older ages (Genotype $\times$ Treatment $\times$ Week: $F_{1,120}=5.55, p<.02$ ). e Prolonged treatment with $C Y$ abolished substrain differences in liver weight by ameliorating hepatomegaly evident in Veh-treated 6-month-old 3xTg-AD mice (males: $p<.001 ;$ females: $p<.01$ ). CY also induced more pronounced weight reduction in WT females $(p<.001)$, than in WT males. $\mathbf{f}$ Vehicle-treated 3xTg-AD mice of both sexes exhibited spleen enlargement which was prevented in CY-treated conspecifics (males: $p<.001$; females: $p<.001$ ). CY treatment in WT females, but not in WT males, also significantly reduced spleen weights in comparison to the Veh group ( $p=.005)$. WT Veh males $(n=16)$, WT CY males $(n=20)$, 3xTg-AD Veh males ( $n=13), 3 \times T g-A D$ CY males ( $n=17)$, WT Veh females $(n=18)$, WT CY females $(n=21)$, 3xTg-AD Veh females $(n=13), 3 \times T g-A D ~ C Y ~ f e m a l e s$ $(n=15)$. Overall group comparisons were carried out using three-way ANOVA (Genotype $\times$ Treatment $\times$ Sex) followed by post hoc $t$ tests. Body weight comparisons were performed using a repeated measures ANOVA with week as a between-subject factor followed by post hoc ANOVAs at each timepoint. Error bars $=\mathrm{SEM},{ }^{*} p \leq .05,{ }^{* *} p<.01,{ }^{* * *} p<.001, \neq=$ Genotype $\times$ Treatment interaction

circulating levels of ANA against double-stranded DNA (dsDNA) in sera were quantified using a fully automated ELISA analyzer (EUROIMMUN Analyzer I) and microtiter plate wells coated with dsDNA complexed with nucleosomes, as described previously [56]. A separate ELISA with microtiter plate wells coated with human $A \beta_{1-42}$ peptide was used to quantify serum anti-A $\beta_{1-42}$ antibody titers, as previously described [80]. Results were expressed as relative optical densities.

Splenocyte single cell suspensions were prepared as described earlier [56] and stained for $\mathrm{T}$ cell surface markers: APC-anti-CD3 (T lymphocyte marker, 1:200, BD Biosciences Pharmingen, San Diego, CA, USA), FITC-anti-CD4 (helper T lymphocyte marker, 1:200, eBioscience, San Diego, CA, USA), PE-anti-CD8 (cytotoxic T lymphocyte marker, 1:200, eBioscience), and PECy7-anti-CD25 (Treg marker, 1:300, eBioscience). For Foxp3 intracellular staining, after staining with the above surface markers, cells were fixed and permeabilized using eBioscience Intracellular Foxp3 Transcription kit for $20 \mathrm{~min}$ and then stained with PerCP-Cy5.5-antiFoxp3 antibody (1:200, eBioscience) for $30 \mathrm{~min}$. Data were acquired with BD FACSCanto (Becton Dickinson, Mississauga, $\mathrm{ON}$ ) and analyzed using FlowJo software (TreeStar, Ashland, OR, USA). Compensation controls were set up with single staining for each of the antibodies, including a negative control, using BD CompBeads (BD Biosciences, San Diego, CA, USA). The gating strategy was based on unstained controls and/or fluorescence-minus-one (FMO) controls. Single and live events were gated based on forward scatter and side scatter plots. For each sample, 100,000 events were acquired, adjusting the forward scatter (FSC) and side scatter (SCC) voltage controls to place the lymphocytes on scale as well as to exclude debris/dead cells.

\section{Assessment of protein markers}

Although the utility of 3xTg-AD mice stems from their age-associated development of both plaque and tangle pathology, emerging data suggests that neuronal dysfunction in $\mathrm{AD}$ is triggered by soluble species rather than insoluble tangles and plaques $[35,45]$. The cortex was selected as the primary tissue of interest, as it is the site of initial intracellular and extracellular neuropathology in 3xTg-AD mice [46, 82]. Extraction of soluble tau and $A \beta$ species was based on published methods [75, 99]. In brief, cortical samples (approx. $100 \mathrm{mg}$ ) were sonicated in tris-buffered saline (TBS) with protease (cOmplete $^{\mathrm{ma}}$ ULTRA Tablets, Mini, EASYpack Protease Inhibitor Cocktail) and phosphatase (PhosSTOP EASYpack, phosphatase inhibitor tablets) inhibitors (Roche, Mississauga, ON, Canada) and kept on ice for 5-10 min. For soluble $A \beta$ analysis, TBS homogenates were centrifuged for $20 \mathrm{~min}$ at $14,000 \times g$ at $4{ }^{\circ} \mathrm{C}$ and supernatants (S1) were collected, aliquoted, and frozen at $-80^{\circ} \mathrm{C}$ until use. For analysis of soluble tau, TBS homogenates were centrifuged for $20 \mathrm{~min}$ at $27,000 \times g$ at $4{ }^{\circ} \mathrm{C}$ and supernatants (S1) were collected for subsequent use. To prepare insoluble tau aggregates, S1 pellets were homogenized in salt/sucrose buffer $[0.8 \mathrm{M} \mathrm{NaCl}, 10 \%$ sucrose, $10 \mathrm{mM}$ Tris/HCl (pH 7.4), $1 \mathrm{mM}$ ethylene glycol-bis $(\beta$-aminoethyl ether)- $\mathrm{N}^{\prime}, \mathrm{N}^{\prime}, \mathrm{N}^{\prime}, \mathrm{N}^{\prime}$-tetraacetic acid, $1 \mathrm{mM}$ phenylmethylsulfonyl fluoride] and centrifuged for $20 \mathrm{~min}$ at $27,000 \times g$ at $4{ }^{\circ} \mathrm{C}$. The resultant supernatant (S2) was adjusted to $1 \%$ sarkosyl, incubated for $1 \mathrm{~h}$ at $37^{\circ} \mathrm{C}$, and centrifuged at $150,000 \times g$ for $1 \mathrm{~h}$ at $4{ }^{\circ} \mathrm{C}$. The sarkosyl- 
insoluble pellet was then re-suspended in TE buffer [10 $\mathrm{mM}$ Tris/ $\mathrm{HCl}$ ( $\mathrm{pH} 8.0$ ), $1 \mathrm{mM}$ ethylene diamine tetraacetic acid] and stored at $-80^{\circ} \mathrm{C}$ for subsequent analysis. Protein concentrations in each fraction were measured using a detergent-compatible protein assay (Bio-Rad Laboratories, Mississauga, ON, Canada).

$\mathrm{A} \beta_{42}$ protein levels in TBS-soluble S1 fractions were measured by Chemiluminescent BetaMark x-42 ELISA per the manufacturer's instructions (BioLegend, San Diego, CA, USA). Concentrations were acquired with a MultiskanGO and SkanIt software (Thermo Scientific, Nepean, ON, Canada) at $620 \mathrm{~nm}$. This ELISA recognizes both mouse and human $A \beta_{42}$, and therefore, mouse $\mathrm{A} \beta_{42}$ values assayed in the corresponding wild-type groups were subtracted as background. Values are presented as pg human $A \beta_{42}$ per mg of total protein.

TBS-soluble and sarkosyl-insoluble total tau and phosphorylated tau were measured using western blotting. Ten and $15 \mu \mathrm{g}$ of total protein were resolved on $10 \%$ gels and transferred to polyvinylidene fluoride membranes (Bio-Rad, Hercules, CA, USA) for analysis of soluble and insoluble tau species, respectively. The membranes were treated as described [75] for detection with primary antibodies anti-tau (tau46, 1:1000; Covance, Princeton, NJ, USA) and anti-phospho-tau (D9F4G, 1:1000; Cell Signaling Technology, Danvers, MA, USA), which recognize both mouse and human tau [89] and incubated in secondary antibodies IRDye 680 -conjugated goat anti-rabbit and IRDye $800 \mathrm{CW}$ conjugated goat anti-mouse $(1: 10,000$, Li-Cor Biosciences, Lincoln, NE, USA). Band intensities were quantified by densitometry by normalizing to mouse $\beta$ actin monoclonal antibody (1:10,000; BioLegend).

\section{Assessment of RNA expression}

RNA was extracted from cortical samples in TRIzol using RNeasy spin columns (Qiagen, Mississauga, ON), complementary DNA was synthesized, and quantitative real-time polymerase chain reaction was performed as described previously [75]. Primers were designed using Primer3 software (http://bioinfo.ut.ee/primer3/) and ordered from IDT (Coralville, IA, USA). BDNF mRNA copy number in each sample was normalized to its $\beta$ - actin mRNA copy number [56, 97]. The macroH2A variant of the canonical histone $\mathrm{H} 2 \mathrm{~A}$ is encoded by two genes that produce distinct proteins, H2afy (encodes mH2A1) and H2afy2 (encodes mH2A2). Expression of both was analyzed as described previously [123]. Genes of interest were normalized against the geometric mean of GAPDH and HPRT, and relative enrichment was normalized to vehicle-treated WT controls. All primer sequences are shown in Table 1.

\section{Statistical analysis}

We previously described Genotype [69] and Sex-related differences in 3xTg-AD mice [56]. However, the focus of this study was significant Genotype $\times$ Treatment $\times$ Sex or Genotype $\times$ Treatment interactions. Raw data analyses were performed using SPSS 20 software (IBM Corp., Armonk, NY, USA). Normal distribution of the data was tested by the Shapiro-Wilk test. When data departed from normality, the overall assumption was that parametric tests were robust enough to detect significant group differences, since the cohorts were independent and population variances were comparable, as revealed by Levene's test. Analysis of variance (ANOVA), ANOVA with repeated measures, analysis of covariance (ANCOVA), and chi-square test were used for group comparisons. Treatment, Genotype, and Sex were considered between-group factors, and Age or Week as within-group factors, where applicable. If significant interactions were detected, Student's $t$ test was used in post hoc comparisons. Partial eta-squared $(\eta 2 p)$ and generalized eta-squared $(\eta 2 \mathrm{~g})$ were used as measures of effect size for all effects and interactions reported for ANOVAs [95] and ANOVA with repeated measures [6], respectively. For reference, Cohen's benchmarks for small (0.01), medium (0.06), and large (0.14) effects are recommended for these measures [27, 37, 95]. Pearson's correlation coefficients were calculated when examining bivariate linear relationships for normal variables. The criterion for statistical significance was set at $p \leq .05$. Graphs display mean values \pm SEM. Significant differences of $p \leq .05, p<.01$, and $p<.001$ are shown as $* *$, and ${ }^{* * * *}$, respectively.

Table 1 Primer sequences used for qRT-PCR

\begin{tabular}{llll}
\hline Gene & Accession & Forward primer & Reverse primer \\
\hline BDNF & NM_001048139.1 & GCGGCAGATAAAAAGACTGC & CTTATGAATCGCCAGCCAAT \\
B-actin & NM_007393.5 & AGCCATGTACGTAGCCATCC & CTCTCAGCTGTGGTGGTGAA \\
H2afy & NM_001159513.1 & CCCGGAAGTCTAAGAAGCAGGG & AGGATTGATTATGGCCTCCACC \\
H2afy2 & NM_207000.2 & CGTCCCCAGTGGCAGAAACT & CCTGCACGTAGATGCCGAT \\
Gapdh & NM_001289726.1 & GTGGAGTCATACTGGAACATGTAG & AATGGTGAAGGTCGGTGTG \\
Hprt & NM_013556.2 & GGAGTCCTGTTGATGTGCCAGTA & GGGACGCAGCAACTGACATTCTA \\
\hline
\end{tabular}




\section{Results}

\section{Peripheral effects}

The earliest observable effects of sustained CY intake were the development of distinct patterns of fur graying in 3xTg-AD mice, noticeable after the second month of exposure. Representative photos exemplify commonly observed ruffled and gray hair in 3xTg-AD males at 6 months of age (Fig. 1b). In contrast, affected agematched 3xTg-AD females exhibited a symmetrical, Vlike pattern of discoloration. These effects were not seen in CY-treated WT controls or in 3xTg-AD mice exposed to vehicle solution. They were not associated with differences in CY dosage, as drug-treated 3xTg-AD and WT groups ingested comparable amounts of $\mathrm{CY}$ when individual intake was measured over single weekends at $\sim 2$ months (Genotype: $F_{1,69}=1.098$, n.s., $\eta 2 \mathrm{p}=.02$; Sex: $F_{1}$, $69=1.20$, n.s., $\eta 2 \mathrm{p}=.02$ ) and $\sim 6$ months of age (Genotype: $F_{1,67}=2.287$, n.s., $\eta 2 \mathrm{p}=.03$; Sex: $F_{1,67}=.314$, n.s., $\eta 2 p=.01$, Fig. 1c). Despite this similarity, CY-treated 3xTg-AD mice showed more profound weight loss than CY-treated WT controls, which became more apparent with time (Genotype $\times$ Treatment $\times$ Week: $F_{9,1080}=$ 3.280, $p<.001, \eta 2 g=.03$, Fig. 1d).

Given a positive correlation between body and liver weight at sacrifice $\left(r_{128}=0.797, p<.001\right)$, body weight was used as a covariate in ANCOVA, which revealed heavier livers in 3xTg-AD mice than in WT controls (Genotype: $F_{1,119}=10.840, p<.001, \eta 2 p=.083$ ). Sustained exposure to $\mathrm{CY}$ reduced liver weight comparably in all groups except in WT male mice (Genotype $x$ Treatment $\times$ Sex: $F_{1,119}=5.207, p=.024, \eta 2 \mathrm{p}=.042$, Fig. 1e). Although exposure to $C Y$ reduced spleen weight in a similar pattern (Treatment: $F_{1,119}=24.743, p<.001$, $\eta 2 \mathrm{p}=.172$, Fig. 1f), this effect was most profound in $3 x$ Tg-AD males $\left(\right.$ Genotype $\times$ Treatment $\times$ Sex: $F_{1,120}=$ 8.259, $p=.005, \eta 2 \mathrm{p}=.065)$.

\section{Splenic T lymphocytes}

The loss of CD4/CD8 markers and the emergence of "double-negative" clones of $\mathrm{T}$ cells are well-established phenomena in systemic autoimmunity [113, 115]. Considering that the spleen is a major source of immune cells [71], we investigated if CY alters the splenic distribution of $\mathrm{T}$ cell populations using flow cytometry. The strategies employed to gate $\mathrm{CD}^{+}, \mathrm{CD}^{+} \mathrm{CD}^{+}$, $\mathrm{CD}^{+} \mathrm{CD}^{+}$, and Foxp $3^{+} \mathrm{CD} 25^{+} \mathrm{CD}^{+}$cells are shown in Fig. 2a. Chronic intake of $\mathrm{CY}$ mitigated the loss of $\mathrm{CD}^{+}$ cells in 3xTg-AD mice, irrespective of sex and without affecting WT controls (Genotype $\times$ Treatment: $F_{1,58}=$ $25.809, p<.001, \eta 2 p=.31$, Fig. 2b). Compared to agematched WT groups (which did not show sex differences), 3xTg-AD males had fewer $\mathrm{CD}^{+}$cells in comparison to their female conspecifics (Genotype $\times$ Sex: $F_{1}$, $58=5.994, p=.017, \eta 2 \mathrm{p}=.09)$. Importantly, CY similarly prevented the decline of $\mathrm{CD}^{+} \mathrm{CD}^{+} \mathrm{T}$ cells (Genotype $\times$ Treatment: $F_{1}, 58=27.923, p<.001, \eta 2 \mathrm{p}=.33$, Fig. 2c) and $\mathrm{CD}^{+} \mathrm{CD}^{+} \mathrm{T}$ cells in 3xTg-AD mice (Genotype $\times$ Treatment: $F_{1,58}=7.136, p=.01, \eta 2 \mathrm{p}=.11$, Fig. $2 \mathrm{~d}$ ). We observed that the proportion of $\mathrm{CD} 4+$ regulatory $\mathrm{T}$ cells (Tregs) expressing CD25 and Foxp3 was higher in both male and female 3xTg-AD mice compared to WT conspecifics (Genotype: $F_{1,32}=101.511, p<.001, \eta 2 \mathrm{p}=.76$, Fig. 2e). Again, chronic intake of CY attenuated the shift in balance towards $T$ regulatory cells in the CD4+ population in 3xTg-AD mice, irrespective of sex and without affecting WT controls (Genotype $\times$ Treatment: $F_{1,32}=$ 31.464, $p<.001, \eta 2 \mathrm{p}=.49$, Fig. 2e).

In our original report [69], we made an attempt to compare lymphocyte populations in the bone marrow (which is a primary lymphoid organ) by flushing cells from the medullary cavity of femoral bones dissected from 1year-old males. We were unable to do this comparison because a needle could not be inserted into the femoral cavity in 3xTg-AD males due to ossification. Furthermore, the femur was solid and pale, suggesting an absence of bone marrow cells (data not reported). Interestingly, in comparison to other groups, sustained CY treatment restored normal, red appearance of the femur of 6-monthold 3xTg-AD males (supplemental data).

\section{Serological measures}

By 6 months of age, 3xTg-AD males (and females to a lesser degree) exhibit robust signs of autoimmunity including low hematocrit and hyperproduction of serum autoantibodies to nuclear antigens [56]. In comparison to Veh controls, prolonged CY exposure lowered hematocrit in all groups except 3xTg-AD males (Genotype $\times$ Treatment $\times$ Sex: $F_{1,73}=8.399, p=.005, \eta 2 \mathrm{p}=$ .10 , Fig. 3a). This genotype- and sex-dependent effect of $\mathrm{CY}$ was accompanied by pronounced alterations in serum autoantibodies to nuclear antigens (ANA; $\chi^{2}=$ 60.596, df $=7, p<.001$, Table 2). Although weak ANA reactivity was noted in 3 out of a total 68 (3/68) CYtreated mice, serum samples from $\sim 60 \%$ of Veh-treated animals showed distinct staining patterns dependent on genotype and sex (Fig. 3b). In particular, a subset of WT control males (3/16) displayed cytoplasmic (Golgi-like) staining, while nearly all 3xTg-AD males (12/13) exhibited moderate to strong homogeneous staining of the nucleus and chromosomes. Interestingly, serum samples from two thirds of Veh WT females also produced staining of the nucleus (9/18) and nucleoli (3/18). In line with these qualitative findings, exposure to $\mathrm{CY}$ reduced serum levels of antibodies to dsDNA in all treated groups (Treatment: $F_{1,119}=45.126, p<.001, \eta 2 \mathrm{p}=.28$, Fig. 3c). However, this mitigation was more prominent in 3xTgAD males, which exhibited higher levels of anti-dsDNA than 3xTg-AD females or WT female controls 


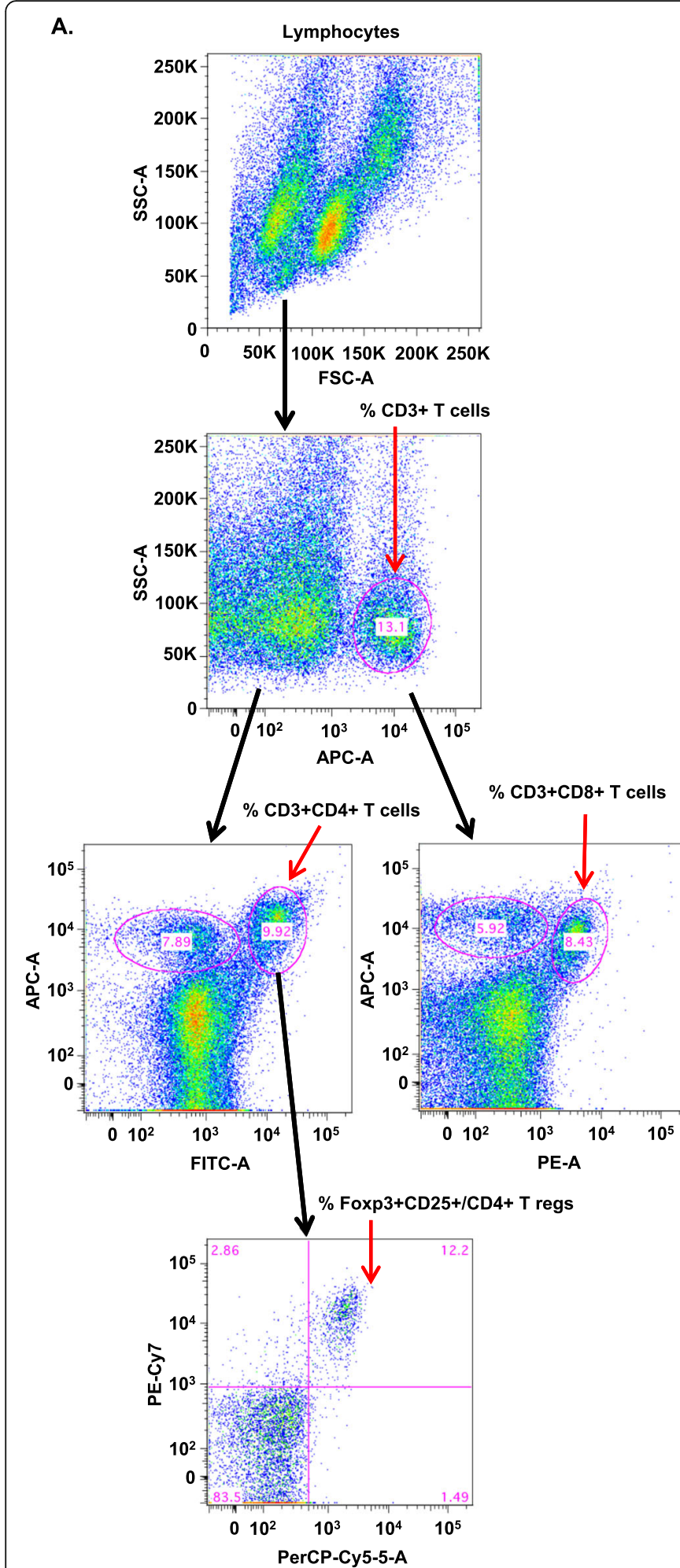

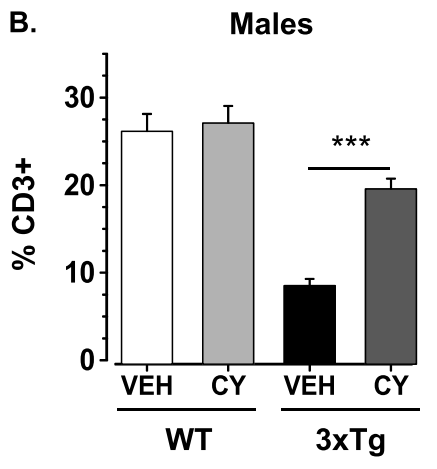

c.

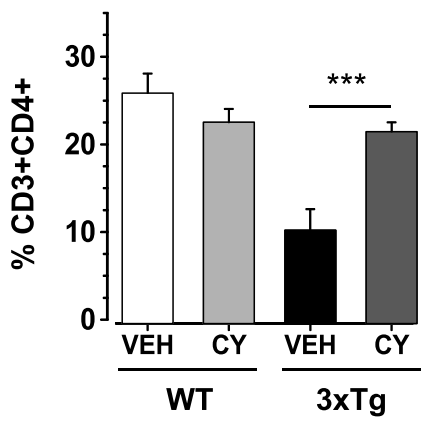

D.
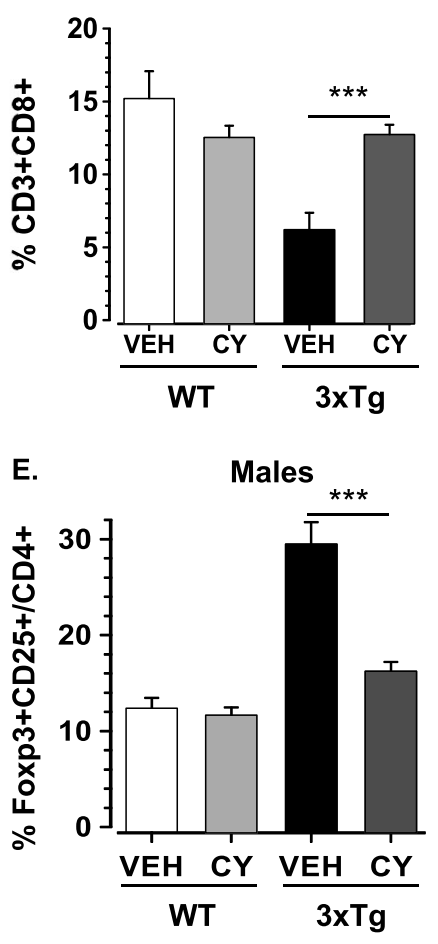

Females

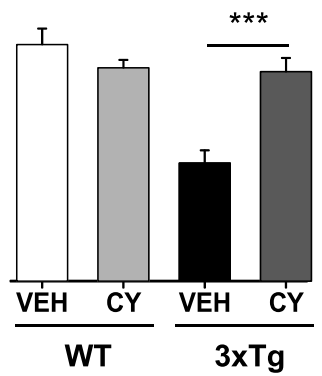

Females

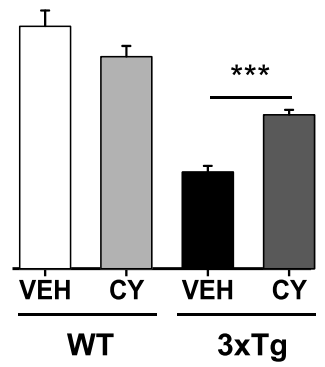

Females

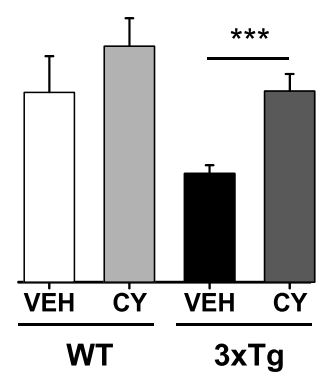

Females

Fig. 2 (See legend on next page.) 
(See figure on previous page.)

Fig. 2 Effects of generalized immunosuppression on T splenocyte populations. a The figure illustrates the gating strategies employed to identify the distribution of T lymphocytes in the spleen. Debris was excluded, and lymphocytes included, using a forward scatter area (FSC-A) versus side scatter area (SSC-A) gate. Single cells (singlets) were then selected on a FSC-A versus FSC-W plot. This population was then analyzed in a FL1/SSC plot in order to quantify the percentage of CD3-APC positive cells. An FL2/FL1 plot was used to quantify the percentage of CD4-FITC and CD3APC positive cells in the total live cell population. Similarly, an FL3/FL1 plot was used to quantify the percentage of CD8-PE and CD3-APC positive cells in the total live cell population. To determine Foxp3+CD25+ Tregs, CD3+CD4+ T cells were further gated on the SSC (FL2) for CD25-PE-Cy7 and FSC (FL1) for Foxp3-PerCP-Cy5.5. The cell population at Q2 are the \% Foxp3+CD25+/CD4+ Tregs. For each sample, 100,000 events were acquired. $\mathbf{b}$ Analysis of splenic T lymphocytes revealed that 3xTg-AD males treated with CY exhibited a significant increase in spleen-derived $\mathrm{CD}^{+} \mathrm{T}$ cells compared to vehicle-treated littermates $(p<.001)$. This effect occurred independent of sex, as CY also normalized low CD ${ }^{+} T$ cells in vehicle-treated 3xTg-AD females $(p<.001)$. The loss of $\mathrm{CD}^{+} \mathrm{T}$ cells was more pronounced in 3xTg-AD males than females $(p<.001)$, while a similar sex difference was not seen in WT controls. c CY partially restored low $C D 3^{+} \mathrm{CD} 4^{+} \mathrm{T}$ cell counts apparent in vehicle-treated $3 \times \mathrm{Tg}$-AD males $(p<.001)$ and females $(p<.001)$. $\mathbf{d}$ CY also normalized low $C D 3^{+} C D 8^{+} T$ cells in the $3 \times T g-A D$ substrain $(p<.001)$ such that levels were comparable to WT controls. e In addition to mitigating the loss of T effector cells, CY treatment abated the rise in the proportion of Foxp3+CD25+/CD4+ Tregs apparent in vehicle-treated 3xTg-AD males $(p<.001)$ and females $(p<.001)$. WT Veh males $(n=5-8)$, WT CY males $(n=5-11)$, 3xTg-AD Veh males $(n=5-7)$, 3xTg-AD CY males ( $n=5-10)$, WT Veh females $(n=5-8)$, WT CY females $(n=5-10)$, 3xTg-AD Veh females $(n=5-6)$, 3xTg-AD CY females $(n=5-6)$. Overall group comparisons were carried out using three-way ANOVA (Genotype $\times$ Treatment $\times$ Sex) followed by post hoc $t$ tests. Error bars $=\mathrm{SEM},{ }^{*} p \leq .05,{ }^{* *} p<.01,{ }^{* * *} p<.001$

(Genotype $\times$ Treatment $\times$ Sex: $F_{1,119}=22.256, p<.001$, $\eta 2 \mathrm{p}=.16)$. Consistent with these effects, $\mathrm{CY}$ also reduced $\mathrm{A} \beta$ antibody titers in all groups (Treatment: $F_{1,120}=$ $36.358, p<.001, \eta 2 \mathrm{p}=.23$, Fig. 3d). Interestingly, this reduction was more pronounced in WT females, where the Veh group showed the highest levels of $A \beta$ autoantibodies (Genotype $\times$ Treatment $\times$ Sex: $F_{1,119}=8.454, p=$ $.004, \eta 2 \mathrm{p}=.07$, Fig. 3d).

\section{Behavior}

Consistent with our previous study [69], data collected with a large behavioral battery demonstrated significant genotype differences in tests of motor coordination/ strength, spontaneous activities, and performance in spatial learning/memory tasks (Table 3). We also documented significant Genotype by Sex interactions in the beam-walking test, spontaneous activities, and reversal learning trials in the Morris water maze. When compared to WT groups, 3xTg-AD females performed better in the beam-walking task of visuomotor coordination (as measured by shorter traversing time) and in the basket test (reflecting muscle strength). 3xTg-AD mice, irrespective of sex, exhibited superior performance in the Rotarod test for balance and endurance, as measured by longer latency to fall compared to WT mice (Genotype: $F_{1}, 123=11.334, p=.001, \eta 2 \mathrm{p}=.083$, Fig. 4a). When tested in the Morris water maze for spatial learning/ memory assessment, male and female $3 \mathrm{xTg}-\mathrm{AD}$ mice swam quicker than age-matched WT controls (Genotype: $F_{1,121}=72.442, p<.001, \eta 2 \mathrm{p}=.374$, Fig. $\left.4 \mathrm{~b}\right)$. The superior performance of 3xTg-AD mice in these measures of basic sensorimotor evaluation rules out general deficits in locomotion or exploration in this strain. Moreover, 3xTg-AD mice did not show robust deficits in Morris water maze acquisition trials in comparison to WT controls, but 3xTg-AD females performed poorer than 3xTg-AD males in reversal acquisition trials. $\mathrm{CY}$ increased water consumption (Treatment: $F_{1,110}=5.136$, $p=.025, \eta 2 \mathrm{p}=.045$; Table 3 ) and food intake (Treatment: $F_{1,113}=5.377, p=.022, \eta 2 \mathrm{p}=.045$; Table 3) in both males and females, irrespective of their genotype and testing age, suggesting that the more robust reductions in body and liver weights in 3xTg-AD mice are not due to reduced caloric or water intake. Importantly, exposure to $\mathrm{CY}$ did not have a significant effect on simple reflexes, olfactory sensitivity, T-maze alternation rate, spontaneous activity, or water maze performance, either at 2 or 6 months of age. These results jointly suggest that basic neurological function, muscle strength, motor coordination, spontaneous locomotion, and learning/memory capacity were not significantly altered by chronic $\mathrm{CY}$ exposure. Our analysis therefore highlights tests which showed significant effects of $\mathrm{CY}$ on genotype and/or sex differences.

Two-month-old 3xTg-AD mice showed a longer latency to step down from an elevated platform than WT controls (Genotype: $F_{1,126}=15.876, p<.001, \eta 2 \mathrm{p}=.11$, Fig. 4c). When re-tested at an older age, CY-treated 3xTg-AD males and WT females were slower to descend than respective Veh-treated controls (Genotype $\times$ Treatment $\times$ Sex: $F_{1,124}=3.921, p=.05, \eta 2 \mathrm{p}=.03$ ).

In the open field test, 3xTg-AD mice defecated more (Genotype: $F_{1,122}=23.332, p<.001, \eta 2 \mathrm{~g}=.160$ ) and traveled less than WT controls (Genotype: $F_{1,123}=13.623$, $p<.001, \eta 2 \mathrm{~g}=.10$; data not shown). Although exposure to $\mathrm{CY}$ failed to abolish these differences, it increased time spent in the center of the arena by 3xTg-AD mice in a sexspecific manner (Genotype $\times$ Treatment $\times$ Sex: $F_{1,124}=$ $4.178, p=.043, \eta 2 g=.03)$. Namely, prolonged exposure to $\mathrm{CY}$ increased center duration in 3xTg-AD males but reduced it in 3xTg-AD females at 6 months (Genotype $\times$ Treatment $\times$ Sex: $F_{1,123}=5.752, p=.018, \eta 2 \mathrm{p}=.05$, data not shown). The time spent in the center of the open field 


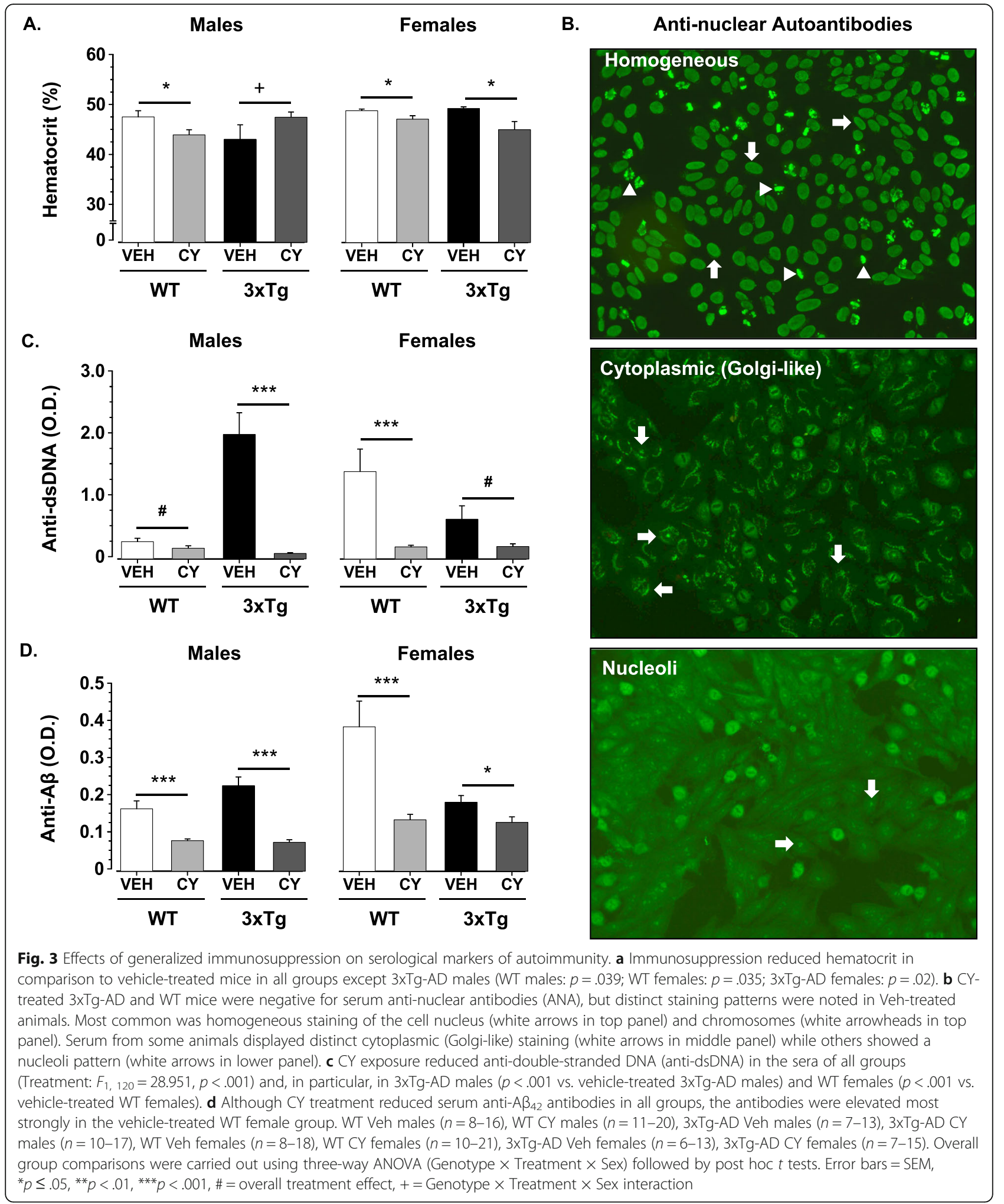

correlated significantly with immobility time (2 months: $r_{134}=.834, p<.001 ; 6$ months: $\left.r_{130}=.874, p<.001\right)$. Videotracking analysis revealed genotype- and sex-specific effects in CY groups (Genotype $\times$ Treatment $\times$ Sex: $F_{1,122}=4.18$, $p=.043, \eta 2 \mathrm{~g}=.03)$. Namely, immobility time was increased significantly in CY-treated 3xTg-AD males when tested at 6 months of age (Genotype $\times$ Treatment $\times$ Sex: $F_{1,122}=$ 4.092, $p=.045, \eta 2 \mathrm{p}=.03$, Fig. $4 \mathrm{~d})$. 
Table 2 Frequencies of serum autoantibodies to nuclear antigens (ANA)

\begin{tabular}{lllll}
\hline Group & ANA positivity rate & Homogeneous ANA pattern & Cytoplasmic (Golgi-like) ANA pattern & Nucleoli ANA pattern \\
\hline WT male VEH & $5 / 16=31.3 \%$ & $2 / 16=12.5 \%$ & $3 / 16=18.6 \%$ & \\
WT male CY & $1 / 20=5 \%$ & $1 / 20=5 \%$ & $1 / 13=7.7 \%$ & \\
3xTg male VEH & $12 / 13=92.3 \%$ & $11 / 13=84.6 \%$ & & $3 / 18=16.7 \%$ \\
$3 \times T$ tg male CY & $0 / 17=0 \%$ & & \\
WT female VEH & $12 / 18=66.7 \%$ & $9 / 18=50 \%$ & $1 / 14=7.1 \%$ \\
WT female CY & $1 / 21=4.8 \%$ & $1 / 21=4.8 \%$ & \\
3XTg female VEH & $4 / 14=28.6 \%$ & $3 / 14=21.4 \%$ & & \\
3xTg female CY & $1 / 15=6.7 \%$ & $1 / 15=6.7 \%$ & & \\
\hline
\end{tabular}

\section{Neuropathology}

Despite abolishing manifestations of systemic autoimmunity, $\mathrm{CY}$ treatment failed to normalize lower brain mass in $\sim 7$-month-old 3xTg-AD mice (Genotype: $F_{1}$, $120=83.032, p<.001, \eta 2 \mathrm{p}=.41$, data not shown). Consistent with a growing consensus that neuronal damage in $\mathrm{AD}$ is triggered by soluble oligomers $[45,106]$, lighter brains in 3xTg-AD mice coincided with sex-dependent differences in TBS-soluble total tau and phospho-tau (Thr181) levels in the cortex (representative western blots are shown in Fig. 5a). Densitometric analysis revealed that 3xTg-AD females had elevated levels of TBSsoluble total tau in comparison to WT controls, but a similar elevation was not noted in 3xTg-AD males (Genotype $\times$ Sex: $F_{1}, 81=18.77, p<.001, \eta 2 \mathrm{p}=.19$, Fig. 5b). 3xTg-AD females also exhibited an increase in phospho-tau in comparison to all other groups (Genotype $\times$ Sex: $F_{1,81}=16.354, p<.001, \eta 2 p=.18$, Fig. 5c). Importantly, immunosuppression with $\mathrm{CY}$ had no appreciable effect on protein levels of TBS-soluble tau or phospho-tau species. In contrast to the findings with TBS-soluble tau species, sarkosyl-insoluble tau levels were not elevated in 3xTg-AD females or males compared to WT (data not shown).

Coinciding with the increase in soluble tau, 3xTg-AD mice also displayed elevated $A \beta_{42}$ levels in TBS-soluble fractions of the cortex (Genotype: $F_{1,68}=193.776$, $p<.001, \eta 2 \mathrm{p}=.74$, Fig. $5 \mathrm{~d}$ ). However, unlike tau, this increase in soluble human $A \beta_{42}$ was greater in $3 x T g-A D$ males than females (Genotype $\times$ Sex: $F_{1,68}=8.921, p=$ $.004, \eta 2 \mathrm{p}=.116 ; 3 \mathrm{xTg}-\mathrm{AD}$ males $>3 \mathrm{xTg}-\mathrm{AD}$ females, $\left.t_{28}=2.249, p=.033\right)$. Although significant Genotype by Sex by Treatment interaction was not detected with the present sample size, between-group comparisons with a $t$ test revealed the most profound effect in $3 x \mathrm{Tg}-\mathrm{AD}$ males (CY-treated < Veh-treated, $t_{15}=3.325, p<.01$ ).

Soluble phospho-tau [97] and A $\beta$ species $[39,86]$ may exert their neurotoxic effects at least in part by downregulating BDNF expression, which is lower in the cortices of 3xTg-AD mice than in WT [56]. Given the essential role of BDNF downregulation in pre-clinical stages of
$\mathrm{AD}[34,87]$ and its links to anxiety-like behaviors [23], we examined BDNF mRNA levels to determine if its cortical expression is altered after generalized immunosuppression. However, CY failed to normalize BDNF expression in 3xTg-AD mice (Genotype: $F_{1,80}=4.575, p=$ $.035, \eta 2 \mathrm{p}=.05$, Fig. 5e).

Histone variants, which replace canonical histones in nucleosomes, were recently implicated in neural plasticity [66, 70, 123] and neurodegeneration [31, 49, 79]. We previously found that $3 \times \mathrm{Tg}-\mathrm{AD}$ males, but not females, exhibit elevated expression of the histone variant macroH2A1 (mH2A1) compared to WT controls [56]. In the current study, 3xTg-AD mice exhibited increased H2afy expression (the mRNA for $\mathrm{mH} 2 \mathrm{~A} 1$ protein) in comparison to age-matched WT controls (Genotype: $F_{1}$, $74=13.238, p<.001, \eta 2 \mathrm{p}=.15)$. Interestingly, CY treatment normalized H2afy expression in the 3xTg-AD substrain (Genotype $\times$ Treatment: $F_{1,74}=5.182, p=.026$, $\eta 2 \mathrm{p}=.07$, Fig. $5 \mathrm{f}$ ). However, although no significant third order interaction was detected with the present sample size, this effect seemed to be driven by CY-treated 3xTgAD females (CY-treated < Veh-treated, $t_{19}=3.148$, $p<.005)$. No significant between-group differences could be detected for H2afy 2 expression (data not shown), suggesting that $\mathrm{CY}$ exposure specifically modulates H2afy expression.

\section{Discussion}

The current 3xTg-AD model exhibits an early anxietylike phenotype that precedes the onset of fluctuating learning/memory deficits, as well as sex-specific markers of systemic autoimmunity and a delay in the progression of AD-like pathology [25, 50, 56, 69]. Here, we demonstrate that systemic immunosuppression failed to attenuate substrain dissimilarities in brain weight, soluble tau/ phospho-tau, BDNF expression, or anxiety-related tasks. However, immunosuppressed 3xTg-AD males had improved hematocrit and lower $A \beta$ load in the cerebral cortex. Compared to 3xTg-AD males, immunosuppressed females developed a distinct pattern of fur discoloration and showed downregulated expression of 
Table 3 Summary of behavioral data collected. Descriptions of methodology and variables tested are described in detail in previous reports [55, 69, 100]

\begin{tabular}{|c|c|c|c|c|c|}
\hline $\begin{array}{l}\text { Behavioral } \\
\text { domain }\end{array}$ & Test & Measure & $\begin{array}{l}\text { Significant test of between- } \\
\text { subject factor(s) }\end{array}$ & $\begin{array}{l}\text { Alterations in } \\
3 \times T g-A D \text { vs. WT }\end{array}$ & $\begin{array}{l}\text { Effect of } \\
\text { immunosuppression }\end{array}$ \\
\hline \multirow{4}{*}{$\begin{array}{l}\text { Sensorimotor } \\
\text { coordination, } \\
\text { strength }\end{array}$} & \multirow[t]{2}{*}{ Beam-walking } & Latency to traverse beam & $\begin{array}{l}\text { Genotype } \times \text { Sex: } F_{1,122}=6.889 \\
p=.010, \eta 2 p=.053\end{array}$ & $\downarrow$ in females & Null \\
\hline & & Beam slips & $\begin{array}{l}\text { Genotype } \times \text { Sex: } F_{1,122}=5.867, \\
p=.017, \eta 2 p=.046\end{array}$ & $\downarrow$ in females & Null \\
\hline & Rotarod & Latency to fall & $\begin{array}{l}\text { Genotype: } F_{1,123}=11.334 \\
p=.001, \eta 2 p=.083\end{array}$ & $\uparrow$ in both sexes & Null \\
\hline & Basket test & Latency to fall & $\begin{array}{l}\text { Genotype } \times \text { Sex: } F_{1,72}=7.449 \\
p=.008, \eta 2 p=.094\end{array}$ & $\uparrow$ in females & Null \\
\hline \multirow[t]{3}{*}{ Sensory } & \multirow{3}{*}{$\begin{array}{l}\text { Olfactory sensitivity } \\
\text { to peanut butter } \\
\text { (PB) }\end{array}$} & $\begin{array}{l}\text { Sniffing duration-0.01\% } \\
\text { PB }\end{array}$ & Not significant & None & Null \\
\hline & & Sniffing duration $-0.1 \%$ PB & $\begin{array}{l}\text { Sex: } F_{1,123}=7.356, p=.008 \\
\eta 2 p=.056\end{array}$ & None & Null \\
\hline & & Sniffing duration-1\% PB & Not significant & None & Null \\
\hline \multirow[t]{15}{*}{$\begin{array}{l}\text { Anxiety-like } \\
\text { behavior }\end{array}$} & \multirow[t]{2}{*}{ Step down } & \multirow[t]{2}{*}{ Latency to descend } & $\begin{array}{l}\text { Genotype: } F_{1,122}=38.334 \\
p<.001, \eta 2 p=.236\end{array}$ & $\uparrow$ in both sexes & \multirow[t]{2}{*}{$\begin{array}{l}\uparrow \text { in } 3 \times T g-A D \text { males } \\
\text { and WT females }\end{array}$} \\
\hline & & & $\begin{array}{l}6 \text { months: Genotype } \times \text { Treatment } \\
\times \text { Sex: } F_{1,124}=3.921, p=.05 \\
\eta 2 p=.03\end{array}$ & $\uparrow$ in both sexes & \\
\hline & \multirow[t]{10}{*}{ Open field } & Fecal boli & $\begin{array}{l}\text { Genotype: } F_{1,122}=23.332 \\
p<.001, \eta 2 p=.16\end{array}$ & $\uparrow$ in both sexes & Null \\
\hline & & Distance moved & $\begin{array}{l}\text { Genotype: } F_{1,123}=13.623 \\
p<.001, \eta 2 p=.1\end{array}$ & $\downarrow$ in both sexes & Null \\
\hline & & $\begin{array}{l}\text { Frequency of visits to } \\
\text { center }\end{array}$ & Not significant & None & Null \\
\hline & & Latency to enter center & Not significant & None & Null \\
\hline & & Distance moved in center & Not significant & None & Null \\
\hline & & $\begin{array}{l}\text { Time spent moving in } \\
\text { center }\end{array}$ & $\begin{array}{l}\text { Genotype } \times \text { Treatment } \times \text { Sex: } F_{1} \\
122=3.970, p=.049, \eta 2 p=.043\end{array}$ & $\uparrow$ in females & $\begin{array}{l}\uparrow \text { in } 3 \times T g-A D \text { males } \\
\text { and } \downarrow \text { in } 3 x T g-A D \\
\text { females }\end{array}$ \\
\hline & & $\begin{array}{l}\text { Time spent immobile in } \\
\text { center }\end{array}$ & $\begin{array}{l}\text { Genotype } \times \text { Treatment } \times \text { Sex: } F_{1} \\
122=4.180, p=.043, \eta 2 p=.033\end{array}$ & $\begin{array}{l}\uparrow \text { in both sexes } \\
\text { (only at } 6 \text { months) }\end{array}$ & $\uparrow$ in $3 \times T$ Tg-AD males \\
\hline & & Thigmotaxis duration & $\begin{array}{l}\text { Genotype: } F_{1,123}=4.525, p=.035 \\
\eta 2 p=.035\end{array}$ & $\begin{array}{l}\downarrow \text { in both sexes } \\
\text { (males only at } 6 \\
\text { months) }\end{array}$ & Null \\
\hline & & \multirow[t]{2}{*}{ Velocity } & $\begin{array}{l}\text { Genotype: } F_{1,123}=5.292, p=.023 \\
\eta 2 p=.041\end{array}$ & \multirow{2}{*}{$\begin{array}{l}\downarrow \text { in both sexes } \\
\text { (females only at } 6 \\
\text { months) }\end{array}$} & \multirow[t]{2}{*}{$\begin{array}{l}\downarrow \text { in both sexes and } \\
\text { strains }\end{array}$} \\
\hline & & & $\begin{array}{l}\text { Treatment: } F_{1,123}=5.062, p=.026, \\
\eta 2 p=.04\end{array}$ & & \\
\hline & \multirow[t]{3}{*}{ Novel object } & Object contact duration & Not significant & None & Null \\
\hline & & Object contact frequency & Not significant & None & Null \\
\hline & & Object contact latency & Not significant & None & Null \\
\hline \multirow[t]{5}{*}{$\begin{array}{l}\text { Spontaneous } \\
\text { behaviors }\end{array}$} & \multirow[t]{5}{*}{$\begin{array}{l}\text { Automated activity } \\
\text { boxes (INBEST) }\end{array}$} & Water intake & $\begin{array}{l}\text { Treatment: } F_{1,110}=5.136, p=.025 \\
\eta 2 p=.045\end{array}$ & None & $\begin{array}{l}\uparrow \text { in both sexes and } \\
\text { strains }\end{array}$ \\
\hline & & \multirow[t]{2}{*}{ Sucrose (4\%) intake } & $\begin{array}{l}\text { Treatment: } F_{1,109}=24.437, \\
p<.001, \eta 2 p=.183\end{array}$ & \multirow[t]{2}{*}{$\downarrow$ in females } & \multirow[t]{2}{*}{$\begin{array}{l}\downarrow \text { in both sexes and } \\
\text { strains }\end{array}$} \\
\hline & & & $\begin{array}{l}\text { Genotype } \times \text { Sex: } F_{1,109}=9.970 \\
p=.002, \eta 2 p=.084\end{array}$ & & \\
\hline & & \multirow[t]{2}{*}{ Food intake } & $\begin{array}{l}\text { Treatment: } F_{1,113}=5.377, p=.022, \\
\eta 2 p=.045\end{array}$ & \multirow[t]{2}{*}{$\begin{array}{l}\uparrow \text { in males (only at } \\
6 \text { months) }\end{array}$} & \multirow[t]{2}{*}{$\begin{array}{l}\uparrow \text { in both sexes and } \\
\text { strains }\end{array}$} \\
\hline & & & $\begin{array}{l}\text { Genotype } \times \text { Sex: } F_{1,113}=6.406 \\
p=.013, \eta 2 p=.054\end{array}$ & & \\
\hline
\end{tabular}


Table 3 Summary of behavioral data collected. Descriptions of methodology and variables tested are described in detail in previous reports $[55,69,100]$ (Continued)

\begin{tabular}{|c|c|c|c|c|c|}
\hline $\begin{array}{l}\text { Behavioral } \\
\text { domain }\end{array}$ & Test & Measure & $\begin{array}{l}\text { Significant test of between- } \\
\text { subject factor(s) }\end{array}$ & $\begin{array}{l}\text { Alterations in } \\
3 \times T g-A D \text { vs. } W T\end{array}$ & $\begin{array}{l}\text { Effect of } \\
\text { immunosuppression }\end{array}$ \\
\hline & & Running wheel rotations & Not significant & None & Null \\
\hline $\begin{array}{l}\text { Working } \\
\text { memory }\end{array}$ & T-maze & $\begin{array}{l}\text { Spontaneous alternation } \\
\text { rate }\end{array}$ & $\begin{array}{l}6 \text { months: Treatment } \times \text { Sex: } F_{1}, \\
131=4.472, \eta 2 p=.036\end{array}$ & None & $\begin{array}{l}\downarrow \text { in males and } \uparrow \text { in } \\
\text { females }\end{array}$ \\
\hline \multirow{14}{*}{$\begin{array}{l}\text { Spatial learning } \\
\text { and memory }\end{array}$} & \multirow{14}{*}{$\begin{array}{l}\text { Morris water } \\
\text { maze }\end{array}$} & Cue trials - path distance & Not significant & None & Null \\
\hline & & Cue trials-latency & $\begin{array}{l}\text { Genotype: } F_{1,122}=8.472, p=.004 \\
\eta 2 p=.065\end{array}$ & $\downarrow$ in both sexes & Null \\
\hline & & Cue trials-velocity & $\begin{array}{l}\text { Genotype: } F_{1,122}=26.806 \\
p<.001, \eta 2 p=.18\end{array}$ & $\uparrow$ in both sexes & Null \\
\hline & & $\begin{array}{l}\text { Acquisition trials_-path } \\
\text { distance }\end{array}$ & $\begin{array}{l}\text { Genotype } \times \text { Timepoint } \times \text { Day: } F_{3,} \\
363=3.502, p=.016, \eta 2 p=.028\end{array}$ & $\begin{array}{l}\uparrow \text { in both sexes (on } \\
\text { day } 1,2 \text { months) }\end{array}$ & Null \\
\hline & & Acquisition trials-latency & Not significant & None & Null \\
\hline & & Acquisition trials—velocity & $\begin{array}{l}\text { Genotype: } F_{1,121}=72.442 \\
p<.001, \eta 2 p=.374\end{array}$ & $\uparrow$ in both sexes & Null \\
\hline & & $\begin{array}{l}\text { Probe trials-time spent in } \\
\text { target quadrant }\end{array}$ & Not significant & None & Null \\
\hline & & $\begin{array}{l}\text { Reversal cue trials_-path } \\
\text { distance }\end{array}$ & $\begin{array}{l}\text { Sex: } F_{1,121}=7.704, p=.006 \\
\eta 2 p=.06\end{array}$ & None & Null \\
\hline & & Reversal cue trials_latency & $\begin{array}{l}\text { Genotype: } F_{1,121}=10.814 \\
p<.001, \eta 2 p=.082\end{array}$ & $\downarrow$ in both sexes & Null \\
\hline & & Reversal cue trials_-velocity & $\begin{array}{l}\text { Genotype: } F_{1,122}=28.250 \\
p<.001, \eta 2 p=.189\end{array}$ & $\uparrow$ in both sexes & Null \\
\hline & & $\begin{array}{l}\text { Reversal acquisition trials- } \\
\text { path distance }\end{array}$ & $\begin{array}{l}\text { Genotype } \times \text { Sex: } F_{1,121}=6.871 \\
p=.01, \eta 2 p=.054\end{array}$ & $\uparrow$ in females & Null \\
\hline & & $\begin{array}{l}\text { Reversal acquisition trials- } \\
\text { latency }\end{array}$ & $\begin{array}{l}\text { Sex: } F_{1,121}=10.416, p=.002 \\
\eta 2 p=.079\end{array}$ & None & Null \\
\hline & & $\begin{array}{l}\text { Reversal acquisition trials- } \\
\text { velocity }\end{array}$ & $\begin{array}{l}\text { Genotype } \times \text { Sex: } F_{1,121}=22.711 \\
p<.001, \eta 2 p=.158\end{array}$ & $\uparrow$ in females & Null \\
\hline & & $\begin{array}{l}\text { Reversal acquisition trials- } \\
\text { time spent in previous } \\
\text { quadrant }\end{array}$ & $\begin{array}{l}\text { Genotype } \times \text { Sex: } F_{1,121}=6.114, \\
p=.015, \eta 2 p=.048\end{array}$ & $\uparrow$ in females & Null \\
\hline
\end{tabular}

histone H2afy mRNA. Taken together, the results from our studies suggest that a sex-related autoimmune response in 3xTg-AD male mice increases soluble A $\beta$ load in the cortex which coincides with altered transcriptional regulation of histone variant H2afy in females. Moreover, it appears that systemic autoimmunity does not fully account for the altered behavioral profile of 3xTg$\mathrm{AD}$ mice. One may hypothesize that emerging autoimmunity is associated with either altered transcriptional regulation that has developed over time, a change in the mixture of background strains, or the pleiotropic effect of human transgenes acting on the immune system directly or via sex hormones. Since information pertaining to the status of the immune system in the original 3xTg$\mathrm{AD}$ cohorts is lacking, the role of human transgenes in accounting for autoimmune manifestations could be addressed in the future by characterizing the immune status of PS1 and tau mice that show spleen enlargement [67]. Since human $A \beta$ has recently been reported in the spleens of 15-month-old 3xTg-AD males [29] and blood of 5-9-month-old 3xTg-AD females [25], we may speculate that peripheral $A \beta$ might further exacerbate peripheral immune responses.

Similar to many patients with mild cognitive impairment [68], enhanced emotionality and anxiety-like behaviors characterize the phenotype of 3xTg-AD mice from an early age and increase in severity over time [38, 41, 50, 69, 108]. Consistent with our work, enhanced emotionality in 6-month-old 3xTg-AD males coincides with an accumulation of soluble $A \beta$ in the amygdala [33]. However, it has been also repeatedly reported that functional impairments in 3xTg-AD mice do not necessarily correlate with $\mathrm{A} \beta$ burden in the brain $[4,30,53$, $72,85,121]$. In the current study, generalized immunosuppression did not abolish anxiety-related behaviors in 3xTg-AD males, but it reduced soluble $\mathrm{A} \beta$ in the cortex. This finding is particularly interesting in light of reports that $A \beta$ itself may have innate immune functions like 
A.

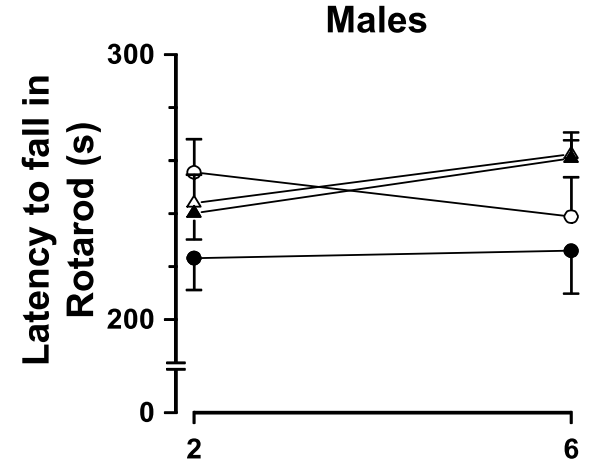

B.

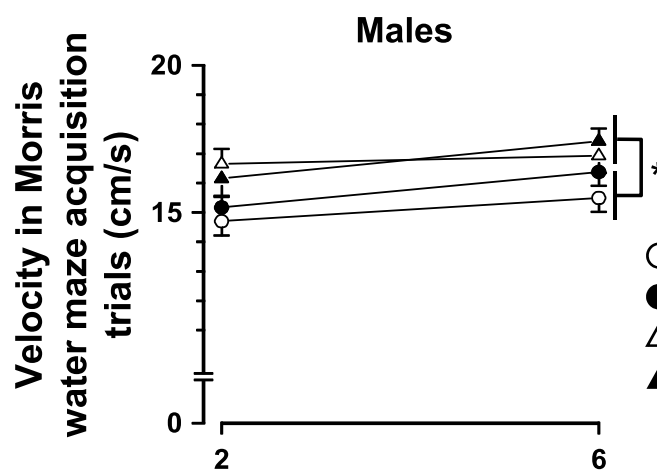

c.

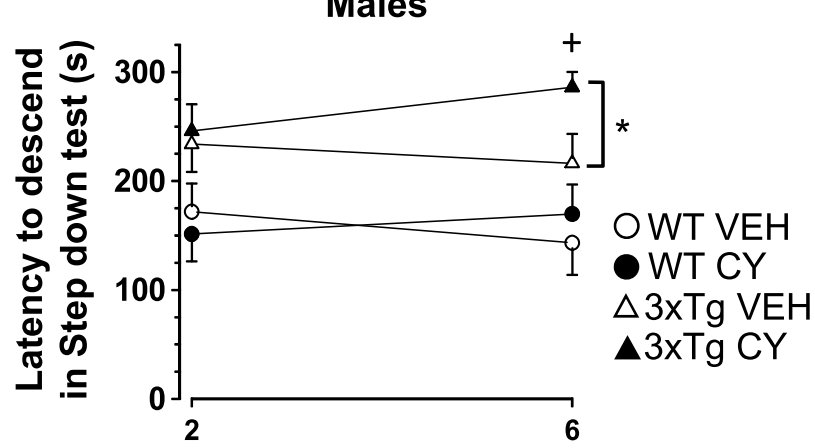

D.

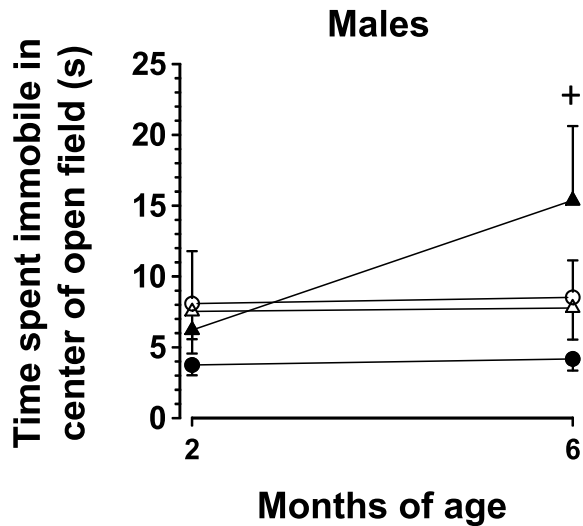

OWT VEH

- WT CY $\triangle 3 \times T g$ VEH $\triangle 3 x \operatorname{T~} C Y$
Females

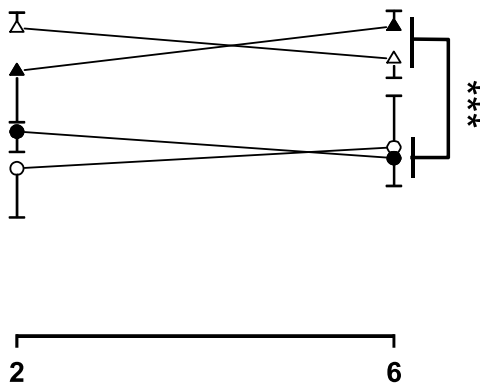

Females

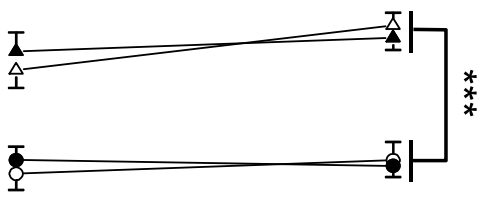

OWT VEH

- WT CY

$\triangle 3 \times T g$ VEH

$\triangle 3 x T g$ CY

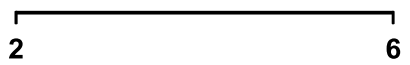

Females

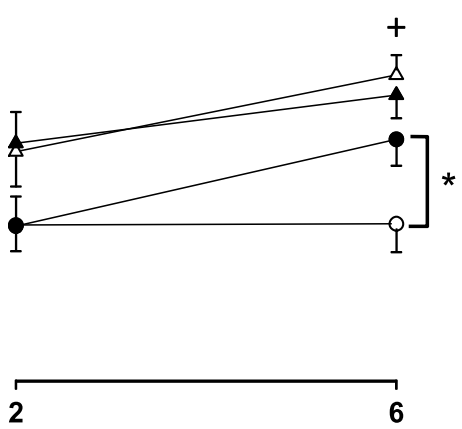

Females

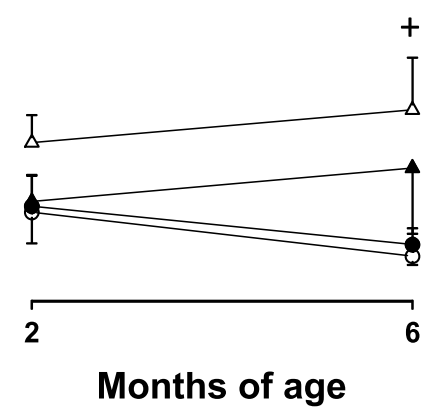

Fig. 4 (See legend on next page.) 
(See figure on previous page.)

Fig. 4 Cyclophosphamide (CY) modulation of anxiety-like behaviors in 3xTg-AD mice at 2 and 6 months of age. a Performance in the Rotarod remained superior for 3xTg-AD mice (triangles), irrespective of sex, in comparison to age-matched WT controls (circles) (Genotype: $F_{1,123}=11.334$, $p=.001, \eta 2 p=.083$ ). Acute or prolonged CY treatment (closed symbols) did not significantly alter the latency to fall off the Rotarod. $\mathbf{b}$ Two- and 6 month-old 3xTg-AD males and females swam faster than age-matched WT controls in the Morris water maze acquisition trials (Genotype: $F_{1,121}=$ $72.442, p<.001, \eta 2 p=.374)$. CY did not alter the swimming speed of 3xTg-AD mice or WT controls. c From an early age, 3xTg-AD males and females took longer than sex-matched WT controls to descend from an elevated platform in the step-down test, consistent with "acrophobia" (Genotype: $F_{1}$, $126=15.876, p<.001)$. After several months of CY exposure, 3xTg-AD males, but not WT controls, took longer to complete the step-down test in comparison to vehicle-treated animals, suggesting that prolonged immunosuppression exacerbated anxiety-like behavior (Genotype $\times$ Treatment $\times$ Sex: $\left.F_{1,124}=3.921, p=.05\right)$. Sustained $C Y$ intake had no discernable impact on the step-down performance of 3xTg-AD females, but WT controls (similar to 3xTg-AD males) took longer to complete the task at 6 months of age. $\mathbf{d}$ In the open field test, CY-treated 3xTg-AD males spent the most time immobile in the center of a large open field (Genotype $\times$ Treatment $\times$ Sex: $\left.F_{1}, 123=4.092, p=.045\right)$. WT Veh males $(n=16)$, WT CY males $(n=20)$, 3xTg-AD Veh males ( $n=13)$, 3xTg-AD CY males ( $n=17)$, WT Veh females $(n=18)$, WT CY females $(n=21)$, 3xTg-AD Veh females $(n=13)$, 3xTg-AD CY females $(n=15)$. Overall group comparisons were carried out using three-way ANOVA (Genotype $\times$ Treatment $\times$ Sex) followed by post hoc $t$ tests. Error bars $=\mathrm{SEM},{ }^{*} p \leq .05,{ }^{* *} p<.01,{ }^{* * *} p<.001, \#=$ overall treatment effect, $+=$ Genotype $\times$ Treatment $\times$ Sex interaction

antimicrobial activity $[63,76]$ and that disruption of immune pathways attenuates $A \beta$ burden [94]. Restoration of increased splenic Foxp3+ Tregs to basal levels has previously been shown to coincide with a reduction in the expression of $A \beta$ in the hippocampus of $3 x T g-A D$ males [29]. Using $C Y$, we see similar lessening of $A \beta$ burden in the cortex of 3xTg-AD males and females. Tregs play a major role in suppression of autoimmune pathology and are often poorly functioning in subjects with autoimmune disease [118]. It is therefore possible that the increase in the proportion of Tregs in 3xTg-AD mice is a protective reaction to enhanced autoimmune responses in these animals. Mitigating the influence of systemic Foxp3+ Treg-mediated immunosuppression on immunocytes may allow a re-balance of the immune response and reduced brain accumulation of $A \beta$ [9]. One may speculate that the altered behavioral performance of 3xTg-AD mice reflects allostatic load due to autoimmune-mediated clearance of neurotoxic aggregates from the brain [105]. Females may not be able to readily mount such an immune response, rendering them vulnerable to plaque/tangle accumulation at older ages. Indeed, we found that $3 \times \mathrm{Tg}-\mathrm{AD}$ females, but not males, exhibit an earlier rise in the amount of total and phosphorylated (Thr181) soluble tau in the cortex in comparison to WT controls. These findings complement recent immunohistochemical data documenting that $100 \%$ of 6-month-old 3xTg-AD females exhibit phospho-tau (Ser202/Thr205 and Ser422) in the hippocampus whereas male 3xTg-AD mice show considerable neuropathological variability [10]. This sex discrepancy in soluble total and phosphorylated tau may help to explain why accumulations of hyperphosphorylated tau tangles are observed in the brains of 12-month-old 3xTg-AD females [25] but not males [69].

Although the production of antibodies to $A \beta$ and other antigens (nuclear and dsDNA) in 3xTg-AD males is consistent with clinical studies reporting autoantibodies in $\mathrm{AD}$ patients [51], their presence in WT females is an unexpected finding that requires further investigation. We previously noted that $\sim 75 \%$ of aged WT males also showed varying degrees of ANA positivity [69]. These unexpected results in the WT mice of both sexes support the notion that the hybrid strain generated from 129 and C57BL/6 mice (ancestor to both the WT and 3xTg-AD strains) is predisposed to spontaneously develop autoimmune manifestations $[18,20]$. However, why the insertion of AD-related genes accelerates the progression of autoimmune manifestations (in males in particular) remains to be determined. Similarly, more data are required to reveal the nature of the sexspecific patterns in depigmentation in 3xTg-AD mice exposed to CY. Hair graying, a typical sign of aging in mammals, has previously been linked to irreparable DNA damage that impairs the maintenance of melanocyte stem cells with age [52]. It remains to be determined if the graying in CY-treated 3xTg-AD mice reflects an increased accumulation of phosphoramide mustard (the cytotoxic metabolite of $\mathrm{CY}$ ) leading to accelerated DNA damage and an early-aging phenotype.

Although the role of histone variants in the CNS is only beginning to be studied, existing data suggest that they are critical regulators of neural plasticity [70, 123]. The transcription of histone variants is highly responsive to environmental stimuli [123], including age-related regulation in the brain [70]. Histone macroH2A is a variant of the canonical histone $\mathrm{H} 2 \mathrm{~A}$ and is encoded by 2 genes that produce distinct proteins, H2afy (encodes mH2A1) and H2afy2 (encodes mH2A2). We recently showed that H2afy, the mRNA for the histone variant mH2A1, is upregulated in the $3 \times \mathrm{Tg}-\mathrm{AD}$ model, which is consistent with studies that demonstrate that $H 2 a f y$ is a marker of disease activity in neurodegenerative disorders [49]. The current study demonstrates that upregulated H2afy transcription can be modified by generalized immunosuppression. This suggests that upregulation of mH2A1 transcription may be driven by immune changes in $\mathrm{AD}$. Since our data are limited to mRNA levels coding 


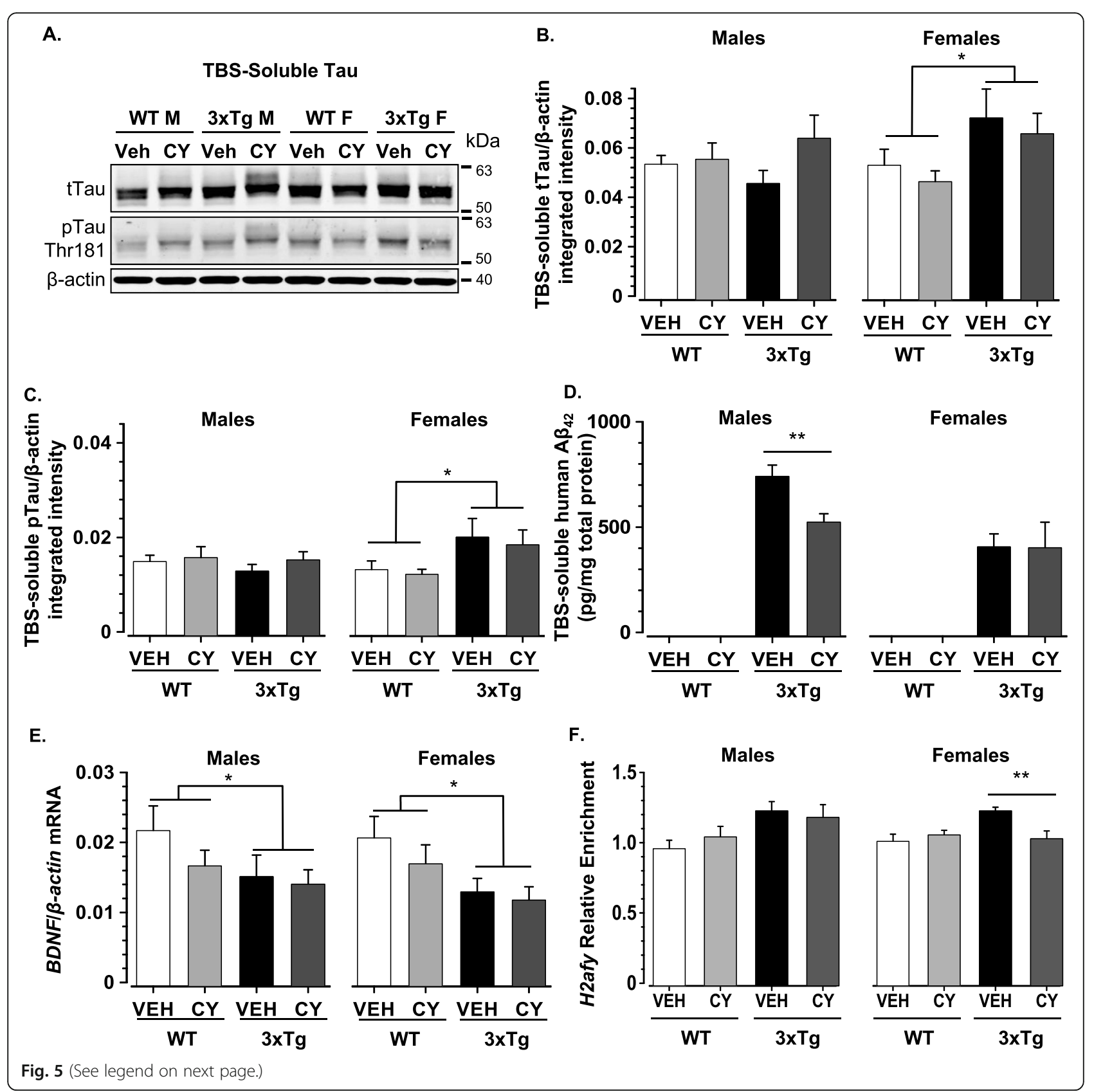




\section{(See figure on previous page.)}

Fig. 5 Effects of generalized immunosuppression on soluble and epigenetic markers of neurodegeneration. a Representative western blot illustrating total tau, phosphorylated tau, and $\beta$-actin protein levels in TBS homogenates extracted from the cortex of 6-month-old mice. $\mathbf{b}$ Densitometric analysis of western blots revealed that 6-month-old 3xTg-AD females had elevated levels of TBS-soluble total tau (normalized to $\beta$ actin) in comparison to WT controls, but this genotype-related difference was not noted in males (Genotype $\times$ Sex: $\left.F_{1,81}=18.77, p<.001\right)$ and was not altered by CY immunosuppression. c 3xTg-AD females also exhibited an increase in phospho-tau (Thr181) in comparison to all other groups (Genotype $\times$ Sex: $F_{1,81}=16.354, p<.001$ ), but $C Y$ had no appreciable effect on the phosphorylation status of tau. $\mathbf{d}$ Soluble human $A \beta_{42}$ was greater in 3xTg-AD males than females (Genotype $\times$ Sex: $F_{1,68}=8.921, p=.004, \eta 2 p=.116$ ). No significant third order interaction was detected, but between-group comparisons with $t$ tests revealed that CY-treated 3xTg-AD males had lower $A \beta_{42}$ load than Veh-treated controls $(p<.01)$. e BDNF mRNA levels were downregulated in 3xTg-AD mice of both sexes compared to controls. $C Y$ did not affect BDNF mRNA levels (normalized to $\beta$-actin) in 3xTg-AD mice. $\mathbf{f} 3 x \mathrm{Tg}$-AD mice treated with vehicle only had significantly higher H2afy mRNA expression compared to controls $(p<.0001)$. CY treatment reversed the upregulated H2afy expression observed in vehicle-treated 3xTg-AD mice compared to WT mice $(p=.046)$. No significant third order interaction was detected, but between-group comparisons with $t$ tests revealed Hzafy downregulation in CYtreated 3xTg-AD females. WT Veh males $(n=11)$, WT CY males $(n=11)$, 3xTg-AD Veh males $(n=9)$, 3xTg-AD CY males $(n=9)$, WT Veh females $(n=13)$, WT CY females ( $n=14)$, 3xTg-AD Veh females $(n=10)$, 3xTg-AD CY females $(n=11)$. Overall group comparisons were carried out using three-way ANOVA (Genotype $\times$ Treatment $\times$ Sex), followed by post hoc $t$ tests. Error bars $=$ SEM, ${ }^{*} p \leq .05,{ }^{* *} p<.01,{ }^{* * *} p<.001$. Abbreviations: A 3 , amyloid-beta; BDNF, brain-derived neurotrophic factor; mRNA, messenger RNA; pTau, phosphorylated tau; tTau, total tau; TBS, tris-buffered saline

for $\mathrm{mH} 2 \mathrm{~A} 1$, we cannot draw conclusions about potential differences in $\mathrm{mH} 2 \mathrm{~A} 1$ histone variant incorporation into the chromatin of 3xTg-AD brains or its reversal with an immunosuppressive drug. However, transcriptional regulation of histone variants is related to altered histone variant incorporation $[70,123]$. The effect of $\mathrm{CY}$ on histone variant expression was restricted to $\mathrm{mH} 2 \mathrm{~A} 1$, suggesting that $\mathrm{mH} 2 \mathrm{~A} 1$ is uniquely responsive to intervention and may play a role in $\mathrm{AD}$ pathology and chromatin dysregulation. However, a larger sample size is required to confirm the sex-specific difference in H2afy mRNA expression and to test its role in regulation of behavioral performance, fur appearance, or autoimmune markers in $3 x \mathrm{Tg}-\mathrm{AD}$ mice.

Taken together, the current study supports the hypothesis that development of systemic autoimmunity in 3xTg-AD mice modulates transcription of H2afy and soluble $A \beta$ accumulation in a sex-specific manner. Since adult 3xTg-AD females show a more profound autoimmune profile than WT females, it is plausible that their intrauterine environment differentially affects brain development during embryogenesis of the offspring [28]. Alternatively, the organizational actions of sex steroid hormones during development are also linked to sex differences in $A \beta$ accumulation in 3xTg-AD mice [21] and represent a future direction of inquiry.

The divergent effects of $\mathrm{CY}$ on certain pathological endpoints are likely due to its broad spectrum of activity as an alkylating agent that irreversibly interferes with the duplication of DNA in cells that divide frequently. While this mechanism of action makes it a potent immunosuppressant, CY may also cause beneficial immunomodulatory effects such as the induction of cytotoxic $\mathrm{CD}^{+} \mathrm{T}$ lymphocytes and $\mathrm{CD}_{4}^{+} \mathrm{T}_{\mathrm{H}} 1$ cells [107]. In keeping with previous observations [81], CY appeared to selectively promote an increase in the effector $\mathrm{T}$ cell population while decreasing the proportion of Tregs. This had the effect of normalizing 3xTg-AD $\mathrm{T}$ cell populations in relation to WT mice. The relative lack of effect on WT controls may seem counterintuitive at first, but is in line with evidence that autoimmune effector cells (including $\mathrm{T}$ cells and $\mathrm{B}$ cells) are uniquely sensitive to high-dose CY [16]. Although we did not count B cells in the current study, circulating autoantibody production was impaired after chronic exposure to $\mathrm{CY}$. CY exhibits relative selectivity for $\mathrm{T}$ cells [1], but its known effects on $\mathrm{B}$ cells [59], dendritic cells [81], and macrophages [17] suggest some of the observed changes in 3xTg-AD mice may be due to differential effects on several immune responses. Although CY is also documented to affect nonimmune cells within the hematologic, cardiovascular, gonadal, and gastrointestinal systems [32], the contribution of such systemic manifestations to AD-like pathology remains an ongoing topic of investigation [122]. While we cannot rule out the possibility that $\mathrm{CY}$ also directly affects soluble $\mathrm{A} \beta$ and expression of histone $\mathrm{mH} 2 \mathrm{~A} 1$ variant, only a small fraction of the alkylating metabolites of $\mathrm{CY}$ have been shown to cross the blood-brain barrier in mice [110]. Since CY and its metabolites may exert multisystem toxicity (immunosuppression is just one of its many effects), further experiments may benefit from more selective blockades of $\mathrm{T}$ cells, B cells, cytokines, or autoantibodies to elucidate terminal factors that account for changes in behavior and protein markers. Lastly, although epigenetic factors are known to be involved in establishing and maintaining immune responses [73], the current study does not reveal the mechanism(s) by which $\mathrm{CY}$ modulates epigenetic pathways.

Although our study points to early, sex-related immune activation as an important phenomenon, careful considerations need to be made when discussing its implications for clinical AD. At best, the 3xTg-AD model is representative of early-onset familial AD caused by genetic mutations in APP and PSEN1, which account for an estimated $1 \%$ or less of all AD-related dementia cases [5]. It remains unclear if familial forms of AD share a 
similar sex discrepancy with late-onset AD. Nevertheless, increasing evidence suggests that sex interacts with genetic factors to modify the risk for AD. For example, women carrying the $\varepsilon 4$ allele of the apolipoprotein $\mathrm{E}$ gene (APOE4), the strongest genetic risk factor for lateonset $\mathrm{AD}$, have a far more pronounced risk of developing $\mathrm{AD}$ than men carrying the allele $[2,120]$. Moreover, several reports suggest that a maternal family history of $\mathrm{AD}$ confers higher risk for developing sporadic $\mathrm{AD}$ than paternal history or no family history [11, 48, 78]. The interactions between sex and genetic factors highlight the possibility that familial forms of $\mathrm{AD}$ may also be affected by sex differences. It also remains unclear to what extent, if any, brain-reactive autoantibodies and Tregs attenuate brain pathology by counteracting neuroinflammation in clinical AD [105]. Despite unknown mechanisms, the $3 x T g-A D$ model may be a valuable in vivo model for studying interactions between autoimmunity and AD-like neurodegenerative brain disorders.

\section{Limitations}

The main limitation of this study is the use of a mouse model that differs substantially in phenotype from its original description in 2003. Namely, the delay in ADlike neuropathology in recent cohorts of male mice and temporal disconnection between plaque/tangle formation and behavioral deficits calls into question the underlying assumptions of the 3xTg-AD model. Nevertheless, the early emergence of spontaneous systemic autoimmunity first detected in 3xTg-AD mice in 2013 suggests a potential mechanism that plays a role in regulating $\mathrm{AD}$-like neurodegeneration, thus begging further investigation.

Our epigenetic data are limited to the measurement of mRNA levels. Therefore, we cannot draw conclusions about potential differences in $\mathrm{mH} 2 \mathrm{~A} 1$ histone variant incorporation into the chromatin of 3xTg-AD brains, or the mechanism by which its transcription is modulated by sustained immunosuppression. Along the same lines, cyclophosphamide affects a broad spectrum of cells and does not allow us to pinpoint which of $\mathrm{T}$ cells, B cells, cytokines, and/or autoantibodies constitute key factors in mediating its effects on multiple molecular and immunological dependent variables. Lastly, although this study reveals sex-specific effects of generalized immunosuppression at different system levels, it does not identify the origin of autoimmune phenomena in $3 \times \mathrm{Tg}$ - AD mice.

A behavioral experiment involving a $2 \times 2 \times 2$ design (with Genotype, Sex, and Treatment as main factors) can be considered an overly ambitious endeavor. Indeed, it required the testing of three separate mouse cohorts to achieve a suitably large sample size $(N>100)$ in order to detect effects of medium size in three sets of variables. Given such a complex design, our project lasted almost
3 years and involved different groups of unbiased experimenters who performed behavioral experiments, which inherently generated variability among groups. Lastly, a behavioral battery followed by multiple comparisons increased the possibility of detecting significant $p$ values by chance and of committing a type I error. We used MANOVA in preliminary data analysis and tempered our interpretations of significant task-specific differences in the "Discussion" section to minimize false inference and overstatement.

\section{Conclusions}

The $3 \mathrm{xTg}$-AD model is characterized by sex-related systemic autoimmunity, early anxiety-like behaviors, and transcriptional changes in epigenetic factors. We show that chronic immunosuppression with $\mathrm{CY}$ prevents hepatosplenomegaly and hypergammaglobulinemia and restores the phenotype of splenic $\mathrm{T}$ cells yet does not improve 3xTg-AD performance in anxiety-related tasks or increase brain mass or BDNF or lower phospho-tau levels. Sex-specific, reduced production of soluble $A \beta$, expression of histone $\mathrm{mH} 2 \mathrm{~A} 1$ variant, and fur graying suggest that chronic $\mathrm{CY}$ exposure has broad spectrum and sex-specific effects on molecular CNS markers and peripheral tissues. Collectively, our work suggests that systemic autoimmunity promotes specific prodromal markers of AD-like pathology and epigenetic markers of neurodegeneration, which jointly may contribute by yet unknown mechanisms to phenotypic alterations in the 3xTg-AD model.

\section{Supplementary Information}

The online version contains supplementary material available at https://doi. org/10.1186/s13195-020-00745-9.

Additional file 1: Supplemental Data. Representative photos of femurs from 6-month old 3xTg-AD mice and WT controls treated with cyclophosphamide or vehicle.

\section{Abbreviations}

3xTg-AD: Triple transgenic mouse model of Alzheimer's disease; AD: Alzheimer's disease; A 3 : Amyloid-beta; ANA: Anti-nuclear antibody; ANOVA: Analysis of variance; ANCOVA: Analysis of covariance; BDNF: Brainderived neurotrophic factor; CY: Cyclophosphamide; dsDNA: Doublestranded DNA; ELISA: Enzyme-linked immunosorbent assay; FMO: Fluorescence-minus-one; FSC: Forward scatter; mH2A1: MacroH2A1; PBS: Phosphate-buffered saline; qRT-PCR: Quantitative reverse transcription polymerase chain reaction; SSC: Side scatter; pTau: Phosphorylated tau; tTau: Total tau; TBS: Tris-buffered saline; WT: Wild-type

\section{Acknowledgements}

We thank Jingpeng Zhai, Isabel Ng, Muriel Tang, Chenchen Tian, Karen Orig, Archita Srivastava, Teresa loana, Jaime Knoch, Olivia Leung, Janice Lee, and Charlotte Yat Au-Yeung for assistance with behavioral testing and analysis.

\section{Authors' contributions}

MK performed the animal studies and post-mortem analyses of tissues, analyzed the data, and wrote the manuscript draft. MFM performed the flow cytometry analysis. DM performed the ANA autoantibody analyses. $\mathrm{CH}$ assisted with the tissue harvesting, data analyses, and manuscript preparation. AA 
and $\mathrm{KN}$ performed the mH2A1 qRT-PCR. CC and BB performed the A $\beta$ antibody analyses. BM performed the post-mortem analyses of tissues. DM and $\mathrm{PF}$ reviewed the manuscript. IZ analyzed the $\mathrm{mH} 2 \mathrm{~A} 1 \mathrm{mRNA}$ expression and helped with the manuscript preparation. MF provided the funding, participated in the study design, and reviewed the manuscript. BS provided the funding, conceived and designed the study, and finalized the manuscript. All authors read and approved the final version of the manuscript.

\section{Funding}

This work was supported by the Canadian Institutes of Health Research (CIHR, PJT-149031) and the Canadian Consortium on Neurodegeneration in Aging (CCNA).

\section{Availability of data and materials}

The datasets used and/or analyzed during the current study are available from the corresponding author on reasonable request.

\section{Ethics approval and consent to participate}

All applicable national (CCAC) and institutional guidelines (McMaster University Animal Ethics Research Board) for the care and use of animals were followed.

\section{Consent for publication}

Not applicable.

\section{Competing interests}

The authors declare that they have no competing interests.

\section{Author details}

${ }^{1}$ Department of Psychiatry and Behavioral Neurosciences, McMaster University, 1280 Main St. West, Hamilton, ON L8S 4K1, Canada. ${ }^{2}$ Department of Medicine, McMaster University, Hamilton, ON, Canada. ${ }^{3}$ Department of Pathology and Molecular Medicine, McMaster University, Hamilton, ON, Canada. ${ }^{4}$ Department of Psychology, Neuroscience, and Behaviour, McMaster University, Hamilton, ON, Canada. ${ }^{5}$ Department of Psychology, University of Toronto Mississauga, Mississauga, ON, Canada. ${ }^{6}$ Department of Pharmaceutical Science, University of South Florida, Tampa, FL, USA. ${ }^{7}$ Department of Translational Science \& Molecular Medicine, Michigan State University, Grand Rapids, MI, USA.

\section{Received: 25 August 2020 Accepted: 7 December 2020}

\section{Published online: 20 January 2021}

\section{References}

1. Ahlmann M, Hempel $G$. The effect of cyclophosphamide on the immune system: implications for clinical cancer therapy. Cancer Chemother Pharmacol. 2016;78:661-71. https://doi.org/10.1007/s00280-016-3152-1.

2. Altmann A, Tian L, Henderson WW, Greicius MD, Alzheimer's Disease Neuroimaging Initiative I. Sex modifies the APOE-related risk of developing Alzheimer disease. Ann Neurol. 2014;75:563-73. https://doi.org/10.1002/ana. 24135.

3. Arranz L, De Castro NM, Baeza I, Gimenez-Llort L, De la Fuente M. Effect of environmental enrichment on the immunoendocrine aging of male and female triple-transgenic 3xTg-AD mice for Alzheimer's disease. J Alzheimers Dis. 2011;25:727-37. https://doi.org/10.3233/JAD-2011-110236.

4. Arsenault D, Dal-Pan A, Tremblay C, Bennett DA, Guitton MJ, De Koninck Y, Tonegawa S, Calon F. PAK inactivation impairs social recognition in 3xTg-AD mice without increasing brain deposition of tau and Abeta. J Neurosci. 2013:33:10729-40. https://doi.org/10.1523/JNEUROSCI.1501-13.2013.

5. Association As. 2019 Alzheimer's disease facts and figures. Alzheimers Dement. 2019;15:321-87. https://doi.org/10.1016/j.jalz.2019.01.010.

6. Bakeman R. Recommended effect size statistics for repeated measures designs. Behav Res Methods. 2005;37:379-84. https://doi.org/10.3758/ bf03192707

7. Balcombe JP, Barnard ND, Sandusky C. Laboratory routines cause animal stress. J Am Assoc Lab Anim Sci. 2004;43:42-51.

8. Bartos A, Fialova L, Svarcova J. Lower serum antibodies against tau protein and heavy neurofilament in Alzheimer's disease. J Alzheimers Dis. 2018;64: 751-60. https://doi.org/10.3233/jad-180039.

9. Baruch K, Rosenzweig N, Kertser A, Deczkowska A, Sharif AM, Spinrad A Tsitsou-Kampeli A, Sarel A, Cahalon L, Schwartz M. Breaking immune tolerance by targeting Foxp3(+) regulatory T cells mitigates Alzheimer's disease pathology. Nat Commun. 2015;6:7967. https://doi.org/10.1038/ ncomms8967.

10. Belfiore R, Rodin A, Ferreira E, Velazquez R, Branca C, Caccamo A, Oddo S. Temporal and regional progression of Alzheimer's disease-like pathology in 3xTg-AD mice. Aging Cell. 2019;18:e12873. https://doi.org/10.1111/acel. 12873.

11. Berti V, Mosconi L, Glodzik L, Li Y, Murray J, De Santi S, Pupi A, Tsui W, De Leon MJ. Structural brain changes in normal individuals with a maternal history of Alzheimer's. Neurobiol Aging. 2011;32:2325 e2317-26. https://doi. org/10.1016/j.neurobiolaging.2011.01.001.

12. Bilkei-Gorzo A. Genetic mouse models of brain ageing and Alzheimer's disease. Pharmacol Ther. 2014;142:244-57. https://doi.org/10.1016/j. pharmthera.2013.12.009.

13. Billings LM, Oddo S, Green KN, McGaugh JL, LaFerla FM. Intraneuronal Abeta causes the onset of early Alzheimer's disease-related cognitive deficits in transgenic mice. Neuron. 2005;45:675-88. https://doi.org/10.1016/j.neuron. 2005.01.040

14. Blazquez G, Canete T, Tobena A, Gimenez-Llort L, Fernandez-Teruel A. Cognitive and emotional profiles of aged Alzheimer's disease (3xTgAD) mice: effects of environmental enrichment and sexual dimorphism. Behav Brain Res. 2014;268:185-201. https://doi.org/10.1016/j.bbr.2014.04.008.

15. Bories C, Guitton MJ, Julien C, Tremblay C, Vandal M, Msaid M, De Koninck Y, Calon F. Sex-dependent alterations in social behaviour and cortical synaptic activity coincide at different ages in a model of Alzheimer's disease. PLoS One. 2012;7:e46111. https://doi.org/10.1371/journal.pone.0046111.

16. Brodsky RA. High-dose cyclophosphamide for autoimmunity and alloimmunity. Immunol Res. 2010;47:179-84. https://doi.org/10.1007/s12026009-8149-y.

17. Bryniarski K, Szczepanik M, Ptak M, Zemelka M, Ptak W. Influence of cyclophosphamide and its metabolic products on the activity of peritoneal macrophages in mice. Pharmacol Rep. 2009;61:550-7. https://doi.org/10. 1016/s1734-1140(09)70098-2.

18. Bygrave AE, Rose KL, Cortes-Hernandez J, Warren J, Rigby RJ, Cook HT, Walport MJ, Vyse TJ, Botto M. Spontaneous autoimmunity in 129 and C57BL/6 mice-implications for autoimmunity described in gene-targeted mice. Plos Biol. 2004;2:E243. https://doi.org/10.1371/journal.pbio.0020243.

19. Canete T, Blazquez G, Tobena A, Gimenez-Llort L, Fernandez-Teruel A. Cognitive and emotional alterations in young Alzheimer's disease (3xTgAD) mice: effects of neonatal handling stimulation and sexual dimorphism. Behav Brain Res. 2015;281:156-71. https://doi.org/10.1016/j.bbr.2014.11.004

20. Carlucci F, Cortes-Hernandez J, Fossati-Jimack L, Bygrave AE, Walport MJ, Vyse TJ, Cook HT, Botto M. Genetic dissection of spontaneous autoimmunity driven by 129-derived chromosome 1 loci when expressed on C57BL/6 mice. J Immunol. 2007;178:2352-60. https://doi.org/10.4049/ jimmunol.178.4.2352.

21. Carroll JC, Rosario ER, Kreimer S, Villamagna A, Gentzschein E, Stanczyk FZ, Pike CJ. Sex differences in beta-amyloid accumulation in 3xTg-AD mice: role of neonatal sex steroid hormone exposure. Brain Res. 2010;1366:233-45. https://doi.org/10.1016/j.brainres.2010.10.009.

22. Chan EKL, Damoiseaux J, Carballo OG, Conrad K, de Melo CW, Francescantonio PLC, Fritzler MJ, Garcia-De La Torre I, Herold M, Mimori T, et al. Report of the first international consensus on standardized nomenclature of antinuclear antibody HEp-2 cell patterns 2014-2015. Front Immunol. 2015;6:412. https://doi.org/10.3389/fimmu.2015.00412.

23. Chen $Z Y$, Jing $D$, Bath $K G$, leraci $A$, Khan $T$, Siao CJ, Herrera DG, Toth $M$, Yang C, BS ME, et al. Genetic variant BDNF (Val66Met) polymorphism alters anxiety-related behavior. Science. 2006;314:140-3. https://doi.org/10.1126/ science.1129663.

24. Chene G, Beiser A, Au R, Preis SR, Wolf PA, Dufouil C, Seshadri S. Gender and incidence of dementia in the Framingham Heart Study from mid-adult life. Alzheimer's Dement. 2015;11:310-20. https://doi.org/10.1016/j.jalz.2013. 10.005 .

25. Cho SM, Lee S, Yang SH, Kim HY, Lee MJ, Kim HV, Kim J, Baek S, Yun J, Kim $D$, et al. Age-dependent inverse correlations in CSF and plasma amyloidbeta(1-42) concentrations prior to amyloid plaque deposition in the brain of 3xTg-AD mice. Sci Rep. 2016;6:20185. https://doi.org/10.1038/srep20185.

26. Clinton LK, Billings LM, Green KN, Caccamo A, Ngo J, Oddo S, McGaugh JL, LaFerla FM. Age-dependent sexual dimorphism in cognition and stress response in the 3xTg-AD mice. Neurobiol Dis. 2007;28:76-82. https://doi. org/10.1016/j.nbd.2007.06.013. 
27. Cohen J. Statistical power analysis for the behavioral sciences. City: Academic press; 2013.

28. Denenberg VH, Mobraaten LE, Sherman GF, Morrison L, Schrott LM, Waters NS, Rosen GD, Behan PO, Galaburda AM. Effects of the autoimmune uterine/maternal environment upon cortical ectopias, behavior and autoimmunity. Brain Res. 1991;563:114-22. https://doi.org/10.1016/00068993(91)91522-3.

29. Di Benedetto G, Burgaletto C, Carta AR, Saccone S, Lempereur L, Mulas G, Loreto C, Bernardini R, Cantarella G. Beneficial effects of curtailing immune susceptibility in an Alzheimer's disease model. J Neuroinflammation. 2019; 16:166. https://doi.org/10.1186/s12974-019-1554-9.

30. Di Meco A, Joshi YB, Lauretti E, Pratico D. Maternal dexamethasone exposure ameliorates cognition and tau pathology in the offspring of triple transgenic AD mice. Mol Psychiatry. 2016;21:403-10. https://doi.org/10.1038/ mp.2015.78.

31. Ehrlich ME, Gandy S. Chromatin plasticity and the pathogenesis of Huntington disease. Proc Natl Acad Sci U S A. 2011;108:16867-8. https://doi. org/10.1073/pnas.1113321108.

32. Emadi A, Jones RJ, Brodsky RA. Cyclophosphamide and cancer: golden anniversary. Nat Rev Clin Oncol. 2009;6:638.

33. Espana J, Gimenez-Llort L, Valero J, Minano A, Rabano A, Rodriguez-Alvarez J, LaFerla FM, Saura CA. Intraneuronal beta-amyloid accumulation in the amygdala enhances fear and anxiety in Alzheimer's disease transgenic mice. Biol Psychiatry. 2010;67:513-21. https://doi.org/10.1016/j.biopsych.2009.06.015.

34. Fahnestock M. Brain-derived neurotrophic factor: the link between amyloid$\beta$ and memory loss. Future Neurol. 2011;6:627-39. https://doi.org/10.2217/ fnl.11.44.

35. Ferreira ST, Lourenco MV, Oliveira MM, De Felice FG. Soluble amyloid-beta oligomers as synaptotoxins leading to cognitive impairment in Alzheimer's disease. Front Cell Neurosci. 2015;9:191. https://doi.org/10.3389/fncel.2015.00191.

36. Ferretti MT, Iulita MF, Cavedo E, Chiesa PA, Schumacher Dimech A, Santuccione Chadha A, Baracchi F, Girouard H, Misoch S, Giacobini E, et al. Sex differences in Alzheimer disease - the gateway to precision medicine. Nat Rev Neurol. 2018;14:457-69. https://doi.org/10.1038/s41582-018-0032-9.

37. Furr RM. Interpreting effect sizes in contrast analysis. Underst Stat. 2004;3:125. https://doi.org/10.1207/s15328031us0301_1.

38. Garcia-Mesa Y, Lopez-Ramos JC, Gimenez-Llort L, Revilla S, Guerra R, Gruart A, Laferla FM, Cristofol R, Delgado-Garcia JM, Sanfeliu C. Physical exercise protects against Alzheimer's disease in 3xTg-AD mice. J Alzheimers Dis. 2011;24:421-54. https://doi.org/10.3233/JAD-2011-101635.

39. Garzon DJ, Fahnestock M. Oligomeric amyloid decreases basal levels of brain-derived neurotrophic factor (BDNF) mRNA via specific downregulation of BDNF transcripts IV and V in differentiated human neuroblastoma cells. J Neurosci. 2007;27:2628-35. https://doi.org/10.1523/JNEUROSCI.5053-06.2007.

40. Gimenez-Llort L, Arranz L, Mate I, De la Fuente M. Gender-specific neuroimmunoendocrine aging in a triple-transgenic 3xTg-AD mouse model for Alzheimer's disease and its relation with longevity. Neuroimmunomodulation. 2008;15:331-43. https://doi.org/10.1159/ 000156475.

41. Gimenez-Llort L, Blazquez G, Canete T, Johansson B, Oddo S, Tobena A, LaFerla FM, Fernandez-Teruel A. Modeling behavioral and neuronal symptoms of Alzheimer's disease in mice: a role for intraneuronal amyloid. Neurosci Biobehav Rev. 2007;31:125-47. https://doi.org/10.1016/..neubiorev. 2006.07.007.

42. Gimenez-Llort L, Garcia Y, Buccieri K, Revilla S, Sunol C, Cristofol R, Sanfeliu C. Gender-specific neuroimmunoendocrine response to treadmill exercise in 3xTg-AD mice. Int J Alzheimers Dis. 2010;2010:128354. https://doi.org/10. 4061/2010/128354

43. Gimenez-Llort L, Rivera-Hernandez G, Marin-Argany M, Sanchez-Quesada JL, Villegas S. Early intervention in the 3xTg-AD mice with an amyloid betaantibody fragment ameliorates first hallmarks of Alzheimer disease. mAbs. 2013:5:665-77. https://doi.org/10.4161/mabs.25424.

44. Guerreiro R, Wojtas A, Bras J, Carrasquillo M, Rogaeva E, Majounie E, Cruchaga C, Sassi C, Kauwe JS, Younkin S, et al. TREM2 variants in Alzheimer's disease. N Engl J Med. 2013;368:117-27. https://doi.org/10.1056/ NEJMoa1211851.

45. Haass C, Selkoe DJ. Soluble protein oligomers in neurodegeneration: lessons from the Alzheimer's amyloid beta-peptide. Nat Rev Mol Cell Biol. 2007;8: 101-12. https://doi.org/10.1038/nrm2101.

46. Hirata-Fukae C, Li HF, Hoe HS, Gray AJ, Minami SS, Hamada K, Niikura T, Hua F, Tsukagoshi-Nagai H, Horikoshi-Sakuraba Y, et al. Females exhibit more extensive amyloid, but not tau, pathology in an Alzheimer transgenic model. Brain Res. 2008;1216:92-103. https://doi.org/10.1016/j.brainres.2008. 03.079.

47. Hollingworth P, Harold D, Sims R, Gerrish A, Lambert JC, Carrasquillo MM, Abraham R, Hamshere ML, Pahwa JS, Moskvina V, et al. Common variants at ABCA7, MS4A6A/MS4A4E, EPHA1, CD33 and CD2AP are associated with Alzheimer's disease. Nat Genet. 2011;43:429-35. https:// doi.org/10.1038/ng.803.

48. Honea RA, Swerdlow RH, Vidoni ED, Burns JM. Progressive regional atrophy in normal adults with a maternal history of Alzheimer disease. Neurology. 2011;76:822-9. https://doi.org/10.1212/WNL.0b013e31820e7b74.

49. Hu Y, Chopra V, Chopra R, Locascio JJ, Liao Z, Ding H, Zheng B, Matson WR, Ferrante RJ, Rosas HD, et al. Transcriptional modulator H2A histone family, member $Y$ (H2AFY) marks Huntington disease activity in man and mouse. Proc Natl Acad Sci U S A. 2011;108:17141-6. https://doi.org/10.1073/pnas, 1104409108.

50. Hutton CP, Lemon JA, Sakic B, Rollo CD, Boreham DR, Fahnestock M, Wojtowicz JM, Becker S. Early intervention with a multi-ingredient dietary supplement improves mood and spatial memory in a triple transgenic mouse model of Alzheimer's disease. J Alzheimers Dis. 2018;64:835-57. https://doi.org/10.3233/JAD-170921.

51. Hyman BT, Smith C, Buldyrev I, Whelan C, Brown H, Tang MX, Mayeux R. Autoantibodies to amyloid-beta and Alzheimer's disease. Ann Neurol. 2001; 49:808-10. https://doi.org/10.1002/ana.1061.

52. Inomata K, Aoto T, Binh NT, Okamoto N, Tanimura S, Wakayama T, Iseki S, Hara E, Masunaga T, Shimizu H, et al. Genotoxic stress abrogates renewal of melanocyte stem cells by triggering their differentiation. Cell. 2009;137: 1088-99. https://doi.org/10.1016/j.cell.2009.03.037.

53. Isopi E, Granzotto A, Corona C, Bomba M, Ciavardelli D, Curcio M, Canzoniero LM, Navarra R, Lattanzio R, Piantelli M, et al. Pyruvate prevents the development of age-dependent cognitive deficits in a mouse model of Alzheimer's disease without reducing amyloid and tau pathology. Neurobiol Dis. 2015;81:214-24. https://doi.org/10.1016/j.nbd.2014.11.013.

54. Janelsins MC, Mastrangelo MA, Oddo S, LaFerla FM, Federoff HJ, Bowers WJ. Early correlation of microglial activation with enhanced tumor necrosis factor-alpha and monocyte chemoattractant protein-1 expression specifically within the entorhinal cortex of triple transgenic Alzheimer's disease mice. J Neuroinflammation. 2005;2:23. https://doi.org/10.1186/17422094-2-23.

55. Kapadia M, Bijelic D, Zhao H, Ma D, Stojanovich L, Milosevic M, Andjus P, Sakic B. Effects of sustained i.c.V. infusion of lupus CSF and autoantibodies on behavioral phenotype and neuronal calcium signaling. Acta neuropathologica communications. 2017;5:70. https://doi.org/10.1186/ s40478-017-0473-1.

56. Kapadia M, Mian MF, Michalski B, Azam AB, Ma D, Salwierz P, Christopher A, Rosa E, Zovkic IB, Forsythe $P$, et al. Sex-dependent differences in spontaneous autoimmunity in adult 3xTg-AD mice. J Alzheimers Dis. 2018: 63:1191-205. https://doi.org/10.3233/JAD-170779.

57. Kapadia M, Zhao H, Ma D, Hatkar R, Marchese M, Sakic B. Zoopharmacognosy in diseased laboratory mice: conflicting evidence. Plos One. 2014;9:e100684. https://doi.org/10.1371/journal.pone.0100684.

58. Kapadia M, Zhao H, Ma D, Sakic B. Sustained immunosuppression alters olfactory function in the MRL model of CNS lupus. J Neurolmmune Pharmacol. 2017;12:555-64. https://doi.org/10.1007/s11481-017-9745-6.

59. Kawabata D, Venkatesh J, Ramanujam M, Davidson A, Grimaldi CM, Diamond B. Enhanced selection of high affinity DNA-reactive B cells following cyclophosphamide treatment in mice. Plos One. 2010;5:e8418. https://doi.org/10.1371/journal.pone.0008418.

60. Kitazawa M, Oddo S, Yamasaki TR, Green KN, LaFerla FM. Lipopolysaccharide-induced inflammation exacerbates tau pathology by a cyclin-dependent kinase 5-mediated pathway in a transgenic model of Alzheimer's disease. J Neurosci. 2005;25:8843-53. https://doi.org/10.1523/ JNEUROSCI.2868-05.2005.

61. Klein SL, Flanagan KL. Sex differences in immune responses. Nat Rev Immunol. 2016;16:626-38. https://doi.org/10.1038/nri.2016.90.

62. Krestova M, Ricny J, Bartos A. Changes in concentrations of tau-reactive antibodies are dependent on sex in Alzheimer's disease patients. J Neuroimmunol. 2018;322:1-8. https://doi.org/10.1016/j.jneuroim.2018.05.004.

63. Kumar DK, Choi SH, Washicosky KJ, Eimer WA, Tucker S, Ghofrani J, Lefkowitz A, McColl G, Goldstein LE, Tanzi RE, et al. Amyloid-beta peptide protects against microbial infection in mouse and worm models of 
Alzheimer's disease. Sci Transl Med. 2016;8:340ra372. https://doi.org/10.1126/ scitranslmed.aaf1059.

64. Lambert JC, Heath S, Even G, Campion D, Sleegers K, Hiltunen M, Combarros O, Zelenika D, Bullido MJ, Tavernier B, et al. Genome-wide association study identifies variants at CLU and CR1 associated with Alzheimer's disease. Nat Genet. 2009;41:1094-9. https://doi.org/10.1038/ ng.439.

65. Laws KR, Irvine K, Gale TM. Sex differences in Alzheimer's disease. Curr Opin Psychiatry. 2018;31:133-9. https://doi.org/10.1097/YCO.0000000000000401.

66. Lepack AE, Bagot RC, Pena CJ, Loh YE, Farrelly LA, Lu Y, Powell SK, Lorsch ZS, Issler O, Cates HM, et al. Aberrant H3.3 dynamics in NAc promote vulnerability to depressive-like behavior. Proc Natl Acad Sci U S A. 2016;113: 12562-7. https://doi.org/10.1073/pnas.1608270113.

67. Levine S, Saltzman A, Levy E, Ginsberg SD. Systemic pathology in aged mouse models of Down's syndrome and Alzheimer's disease. Exp Mol Pathol. 2009;86:18-22. https://doi.org/10.1016/j.yexmp.2008.10.006.

68. Mah L, Binns MA, Steffens DC, Alzheimer's Disease Neuroimaging I. Anxiety symptoms in amnestic mild cognitive impairment are associated with medial temporal atrophy and predict conversion to Alzheimer disease. Am J Geriatr Psychiatry. 2015;23:466-76. https://doi.org/10.1016/j.jagp.2014.10.005.

69. Marchese M, Cowan D, Head E, Ma D, Karimi K, Ashthorpe V, Kapadia M, Zhao H, Davis P, Sakic B. Autoimmune manifestations in the 3xTg-AD model of Alzheimer's disease. J Alzheimers Dis. 2014;39:191-210. https://doi.org/10.3233/JAD-131490.

70. Maze I, Wenderski W, Noh KM, Bagot RC, Tzavaras N, Purushothaman I, Elsasser SJ, Guo Y, lonete C, Hurd YL, et al. Critical role of histone turnover in neuronal transcription and plasticity. Neuron. 2015;87:77-94. https://doi. org/10.1016/.neuron.2015.06.014.

71. Mebius RE, Kraal G. Structure and function of the spleen. Nat Rev Immunol. 2005;5:606-16. https://doi.org/10.1038/nri1669

72. Medeiros R, Castello NA, Cheng D, Kitazawa M, Baglietto-Vargas D, Green KN, Esbenshade TA, Bitner RS, Decker MW, LaFerla FM. alpha7 Nicotinic receptor agonist enhances cognition in aged 3xTg-AD mice with robust plaques and tangles. Am J Pathol. 2014;184:520-9. https://doi.org/10.1016/j.ajpath.2013.10.010.

73. Mehta S, Jeffrey KL. Beyond receptors and signaling: epigenetic factors in the regulation of innate immunity. Immunol Cell Biol. 2015;93:233-44. https://doi.org/10.1038/icb.2014.101

74. Meijer MK, Spruijt BM, van Zutphen LF, Baumans V. Effect of restraint and injection methods on heart rate and body temperature in mice. Lab Anim. 2006:40:382-91. https://doi.org/10.1258/002367706778476370.

75. Michalski B, Corrada MM, Kawas CH, Fahnestock M. Brain-derived neurotrophic factor and TrkB expression in the "oldest-old," the 90+ Study: correlation with cognitive status and levels of soluble amyloid-beta. Neurobiol Aging. 2015;36:3130-9. https://doi.org/10.1016/j.neurobiolaging. 2015.08.022.

76. Moir RD, Lathe R, Tanzi RE. The antimicrobial protection hypothesis of Alzheimer's disease. Alzheimer's Dement. 2018;14:1602-14. https://doi.org/ 10.1016/j.jalz.2018.06.3040.

77. Monsonego A, Nemirovsky A, Harpaz I. CD4 T cells in immunity and immunotherapy of Alzheimer's disease. Immunology. 2013;139:438-46.

78. Mosconi L, Berti V, Swerdlow RH, Pupi A, Duara R, de Leon M. Maternal transmission of Alzheimer's disease: prodromal metabolic phenotype and the search for genes. Human Genomics. 2010;4:170-93. https://doi.org/10. 1186/1479-7364-4-3-170.

79. Myung NH, Zhu X, Kruman CRJ II, Petersen RB, Siedlak SL, Perry G, Smith MA, Lee HG. Evidence of DNA damage in Alzheimer disease: phosphorylation of histone H2AX in astrocytes. Age (Dordrecht). 2008;30: 209-15. https://doi.org/10.1007/s11357-008-9050-7.

80. Nabar NR, Yuan F, Lin X, Wang L, Bai G, Mayl J, Li Y, Zhou SF, Wang J, Cai J, et al. Cell therapy: a safe and efficacious therapeutic treatment for Alzheimer's disease in APP+PS1 mice. Plos One. 2012;7:e49468. https:/doi. org/10.1371/journal.pone.0049468.

81. Nakahara T, Uchi H, Lesokhin AM, Avogadri F, Rizzuto GA, HirschhornCymerman D, Panageas KS, Merghoub T, Wolchok JD, Houghton AN. Cyclophosphamide enhances immunity by modulating the balance of dendritic cell subsets in lymphoid organs. Blood. 2010;115:4384-92. https:// doi.org/10.1182/blood-2009-11-251231.

82. Oddo S, Caccamo A, Shepherd JD, Murphy MP, Golde TE, Kayed R, Metherate R, Mattson MP, Akbari Y, LaFerla FM. Triple-transgenic model of Alzheimer's disease with plaques and tangles: intracellular Abeta and synaptic dysfunction. Neuron. 2003;39:409-21. https://doi.org/10.1016/ s0896-6273(03)00434-3.
83. Oddo S, Caccamo A, Tran L, Lambert MP, Glabe CG, Klein WL, LaFerla FM. Temporal profile of amyloid-beta (Abeta) oligomerization in an in vivo model of Alzheimer disease. A link between Abeta and tau pathology. J Biol Chem. 2006:281:1599-604.

84. Oddo S, Caccamo A, Tseng B, Cheng D, Vasilevko V, Cribbs DH, LaFerla FM. Blocking Abeta42 accumulation delays the onset and progression of tau pathology via the $\mathrm{C}$ terminus of heat shock protein70-interacting protein: a mechanistic link between Abeta and tau pathology. J Neurosci. 2008;28: 12163-75. https://doi.org/10.1523/JNEUROSCI.2464-08.2008.

85. Oddo S, Vasilevko V, Caccamo A, Kitazawa M, Cribbs DH, LaFerla FM. Reduction of soluble Abeta and tau, but not soluble Abeta alone, ameliorates cognitive decline in transgenic mice with plaques and tangles. J Biol Chem. 2006;281:39413-23. https://doi.org/10.1074/jbc. M608485200.

86. Peng S, Garzon DJ, Marchese M, Klein W, Ginsberg SD, Francis BM, Mount $H T$, Mufson EJ, Salehi A, Fahnestock M. Decreased brain-derived neurotrophic factor depends on amyloid aggregation state in transgenic mouse models of Alzheimer's disease. J Neurosci. 2009;29:9321-9. https:// doi.org/10.1523/JNEUROSCI.4736-08.2009.

87. Peng S, Wuu J, Mufson EJ, Fahnestock M. Precursor form of brain-derived neurotrophic factor and mature brain-derived neurotrophic factor are decreased in the pre-clinical stages of Alzheimer's disease. J Neurochem. 2005;93:1412-21. https://doi.org/10.1111/j.1471-4159.2005.03135.x.

88. Perez SE, He B, Muhammad N, Oh KJ, Fahnestock M, Ikonomovic MD, Mufson EJ. Cholinotrophic basal forebrain system alterations in 3xTg-AD transgenic mice. Neurobiol Dis. 2011;41:338-52. https://doi.org/10.1016/j. nbd.2010.10.002.

89. Petry FR, Pelletier J, Bretteville A, Morin F, Calon F, Hebert SS, Whittington RA, Planel E. Specificity of anti-tau antibodies when analyzing mice models of Alzheimer's disease: problems and solutions. Plos One. 2014;9:e94251. https://doi.org/10.1371/journal.pone.0094251.

90. Pietropaolo S, Feldon J, Yee BK. Age-dependent phenotypic characteristics of a triple transgenic mouse model of Alzheimer disease. Behav Neurosci. 2008;122:733-47. https://doi.org/10.1037/a0012520.

91. Pietropaolo S, Sun Y, Li R, Brana C, Feldon J, Yee BK. Limited impact of social isolation on Alzheimer-like symptoms in a triple transgenic mouse model. Behav Neurosci. 2009;123:181-95. https://doi.org/10.1037/a0013607.

92. Rae EA, Brown RE. The problem of genotype and sex differences in life expectancy in transgenic AD mice. Neurosci Biobehav Rev. 2015;57:238-51. https://doi.org/10.1016/j.neubiorev.2015.09.002.

93. Rajamohamedsait H, Rasool S, Rajamohamedsait W, Lin Y, Sigurdsson EM. Prophylactic active tau immunization leads to sustained reduction in both tau and amyloid- $\beta$ pathologies in 3xTg mice. Sci Rep. 2017;7:17034. https:// doi.org/10.1038/s41598-017-17313-1.

94. Reed-Geaghan EG, Reed QW, Cramer PE, Landreth GE. Deletion of CD14 attenuates Alzheimer's disease pathology by influencing the brain's inflammatory milieu. J Neurosci. 2010;30:15369-73. https://doi.org/10.1523/ jneurosci.2637-10.2010

95. Richardson JTE. Eta squared and partial eta squared as measures of effect size in educational research. Educ Res Rev. 2011;6:135-47. https://doi.org/10. 1016/.edurev.2010.12.001.

96. Roddick KM, Roberts AD, Schellinck HM, Brown RE. Sex and genotype differences in odor detection in the 3XTg-AD and 5XFAD mouse models of Alzheimer's disease at 6 months of age. Chem Senses. 2016;41:433-40. https://doi.org/10.1093/chemse/bjw018.

97. Rosa E, Mahendram S, Ke YD, Ittner LM, Ginsberg SD, Fahnestock M. Tau downregulates BDNF expression in animal and cellular models of Alzheimer's disease. Neurobiol Aging. 2016;48:135-42. https://doi.org/10. 1016/..neurobiolaging.2016.08.020.

98. Ryabinin AE, Wang YM, Finn DA. Different levels of Fos immunoreactivity after repeated handling and injection stress in two inbred strains of mice. Pharmacol Biochem Behav. 1999;63:143-51. https://doi.org/10.1016/s00913057(98)00239-1.

99. Sahara N, DeTure M, Ren Y, Ebrahim AS, Kang D, Knight J, Volbracht C, Pedersen JT, Dickson DW, Yen SH, et al. Characteristics of TBS-extractable hyperphosphorylated tau species: aggregation intermediates in $\mathrm{rTg} 4510$ mouse brain. J Alzheimers Dis. 2013;33:249-63. https://doi.org/10.3233/JAD2012-121093.

100. Sakic B, Cooper MP, Taylor SE, Stojanovic M, Zagorac B, Kapadia M. Behavioral phenotyping of murine disease models with the Integrated Behavioral Station (INBEST). J Vis Exp. 2015. https://doi.org/10.3791/51524. 
101. Sakic B, Denburg JA, Denburg SD, Szechtman H. Blunted sensitivity to sucrose in autoimmune MRL-Ipr mice: a curve-shift study. Brain Res Bull. 1996;41:305-11. https://doi.org/10.1016/s0361-9230(96)00190-6.

102. Sakic B, Kolb B, Whishaw IQ, Gorny G, Szechtman H, Denburg JA. Immunosuppression prevents neuronal atrophy in lupus-prone mice: evidence for brain damage induced by autoimmune disease? J Neuroimmunol. 2000;111:93-101. https://doi.org/10.1016/s01655728(00)00364-7.

103. Sakic B, Szechtman H, Denburg SD, Denburg JA. Immunosuppressive treatment prevents behavioral deficit in autoimmune MRL-Ipr mice. Physiol Behav. 1995;58:797-802. https://doi.org/10.1016/0031-9384(95)00135-6.

104. Sardi F, Fassina L, Venturini L, Inguscio M, Guerriero F, Rolfo E, Ricevuti G. Alzheimer's disease, autoimmunity and inflammation. The good, the bad and the ugly. Autoimmun Rev. 2011;11:149-53.

105. Schwartz M, Baruch K. Breaking peripheral immune tolerance to CNS antigens in neurodegenerative diseases: boosting autoimmunity to fight-off chronic neuroinflammation. J Autoimmun. 2014;54:8-14. https://doi.org/10. 1016/j.jaut.2014.08.002.

106. Shankar GM, Li S, Mehta TH, Garcia-Munoz A, Shepardson NE, Smith I, Brett FM, Farrell MA, Rowan MJ, Lemere CA, et al. Amyloid-beta protein dimers isolated directly from Alzheimer's brains impair synaptic plasticity and memory. Nat Med. 2008;14:837-42. https://doi.org/10.1038/nm1782.

107. Sistigu A, Viaud S, Chaput N, Bracci L, Proietti E, Zitvogel L. Immunomodulatory effects of cyclophosphamide and implementations for vaccine design. Semin Immunopathol. 2011;33:369-83. https://doi.org/10. 1007/s00281-011-0245-0.

108. Sterniczuk R, Antle MC, Laferla FM, Dyck RH. Characterization of the 3xTg-AD mouse model of Alzheimer's disease: part 2. Behavioral and cognitive changes. Brain Res. 2010;1348:149-55. https://doi.org/10.1016/j. brainres.2010.06.011.

109. Stevens LM, Brown RE. Reference and working memory deficits in the 3xTgAD mouse between 2 and 15-months of age: a cross-sectional study. Behav Brain Res. 2015;278:496-505. https://doi.org/10.1016/j.bbr.2014.10.033.

110. Stewart C, Campagne O, Davis A, Zhong B, Nair S, Haberman V, Y TP, Janke L, M FR (2019) CNS penetration of cyclophosphamide and metabolites in mice bearing group 3 medulloblastoma and non-tumor bearing mice. J Pharm Pharm Sci 22: 612-629 doi https://doi.org/10.18433/jpps30608.

111. Storace D, Cammarata S, Borghi R, Sanguineti R, Giliberto L, Piccini A, Pollero V, Novello C, Caltagirone C, Smith MA, et al. Elevation of \{beta\}amyloid 1-42 autoantibodies in the blood of amnestic patients with mild cognitive impairment. Arch Neurol. 2010;67:867-72. https://doi.org/10.1001/ archneurol.2010.137.

112. Stover KR, Campbell MA, Van Winssen CM, Brown RE. Early detection of cognitive deficits in the 3xTg-AD mouse model of Alzheimer's disease. Behav Brain Res. 2015;289:29-38. https://doi.org/10.1016/j.bbr.2015.04.012.

113. Strober S, Cheng L, Zeng D, Palathumpat R, Dejbakhsh-Jones S, Huie P, Sibley R. Double negative (CD4-CD8- alpha beta+) T cells which promote tolerance induction and regulate autoimmunity. Immunol Rev. 1996;149: 217-30. https://doi.org/10.1111/j.1600-065x.1996.tb00906.x.

114. Sy M, Kitazawa M, Medeiros R, Whitman L, Cheng D, Lane TE, Laferla FM. Inflammation induced by infection potentiates tau pathological features in transgenic mice. Am J Pathol. 2011;178:2811-22. https://doi.org/10.1016/j. ajpath.2011.02.012.

115. Thomson CW, Lee BP, Zhang L. Double-negative regulatory T cells: nonconventional regulators. Immunol Res. 2006;35:163-78. https://doi.org/10. 1385/IR:35:1:163

116. Torres-Lista V, Gimenez-Llort L. Early postnatal handling and environmenta enrichment improve the behavioral responses of 17-month-old 3xTg-AD and non-transgenic mice in the Forced Swim Test in a gender-dependent manner. Behav Process. 2015;120:120-7. https://doi.org/10.1016/j.beproc. 2015.09.011

117. Torres-Lista V, Gimenez-Llort L. Impairment of nesting behaviour in 3xTg-AD mice. Behav Brain Res. 2013;247:153-7. https://doi.org/10.1016/ j.bbr.2013.03.021.

118. Trinath J, Bayry J. Current trends with FOXP3+ regulatory T cell immunotherapy to contest autoimmunity and inflammation. Immunotherapy. 2019;11:755-8. https://doi.org/10.2217/imt-2019-0069.

119. Tseng BP, Green KN, Chan JL, Blurton-Jones M, LaFerla FM. Abeta inhibits the proteasome and enhances amyloid and tau accumulation. Neurobiol Aging. 2008;29:1607-18. https://doi.org/10.1016/j.neurobiolaging.2007.04. 014.
120. Ungar L, Altmann A, Greicius MD. Apolipoprotein E, gender, and Alzheimer's disease: an overlooked, but potent and promising interaction. Brain Imaging Behav. 2014;8:262-73. https://doi.org/10.1007/s11682-013-9272-x.

121. Van der Jeugd A, Parra-Damas A, Baeta-Corral R, Soto-Faguas CM, Ahmed T, LaFerla FM, Gimenez-Llort L, D'Hooge R, Saura CA. Reversal of memory and neuropsychiatric symptoms and reduced tau pathology by selenium in 3xTg-AD mice. Sci Rep. 2018;8:6431. https://doi.org/10.1038/s41598-01824741-0.

122. Wang J, Gu BJ, Masters CL, Wang Y-J. A systemic view of Alzheimer disease — insights from amyloid- $\beta$ metabolism beyond the brain. Nat Rev Neurol. 2017;13:612-23. https://doi.org/10.1038/nrneurol.2017.111.

123. Zovkic IB, Paulukaitis BS, Day JJ, Etikala DM, Sweatt JD. Histone H2A.Z subunit exchange controls consolidation of recent and remote memory. Nature. 2014;515:582-6. https://doi.org/10.1038/nature13707.

\section{Publisher's Note}

Springer Nature remains neutral with regard to jurisdictional claims in published maps and institutional affiliations.
Ready to submit your research? Choose BMC and benefit from:

- fast, convenient online submission

- thorough peer review by experienced researchers in your field

- rapid publication on acceptance

- support for research data, including large and complex data types

- gold Open Access which fosters wider collaboration and increased citations

- maximum visibility for your research: over $100 \mathrm{M}$ website views per year

At BMC, research is always in progress.

Learn more biomedcentral.com/submissions 